\title{
واقـع تفعيـل الإدارة المدرسيـة للشراكـة المجتمعيــة وفـق متطلبـات إدارة الأزمات التعليمية بسلطنة عُمان
}

\section{نصرة بنت صالح العبرية'، أيمن أحمد العُمري² أمل بنت راشد الكيومية3}

1 طالبة دراسات عليا- قسم الأصول والإدارة التربوية- كلية التربية- جامعة السلطان قابوس- سلطنة عُمان

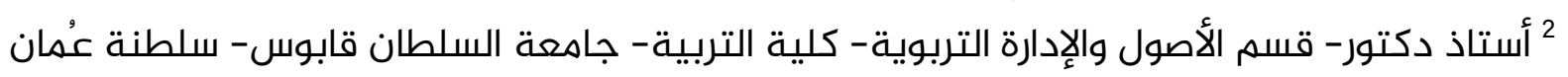
3 أستاذ مساعد- قسم الأصول والإدارة التربوية- كلية التربية- جادعة السلطان قابوس- سلطية سلطنة عُمان ${ }^{1}$ nasra.alabri@moe.om, ${ }^{2}$ a.alomari@squ.edu.om, ${ }^{3}$ kiyomi@squ.edu.om 


\title{
و اقع تفعيل الإدارة المدرسية للشر اكة المجتمعية وفق متطلبات إدارة الأزمات التعليمية
}

\section{بسلطنة عُمان}

\author{
نصرة بنت صالح العبرية'، أيمن أحمد العُمري²، أمل بنت راشـد الكيومية33 \\ 1 طالبة دراسات عليا- قسم الأصهول والإدارة التربوية- كلية التربية- جامعة السلطان قابوس- سلطنة عُمان

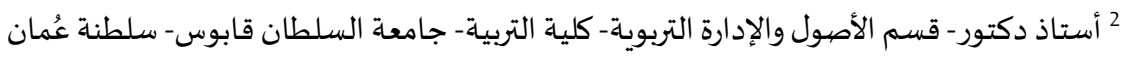

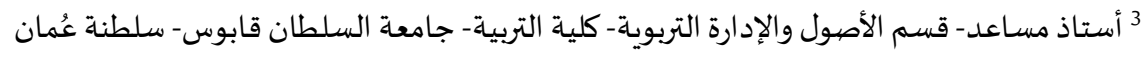 \\ 1 nasra.alabri@moe.om, ${ }^{2}$ a.alomari@squ.edu.om, ${ }^{3}$ kiyomi@squ.edu.om
}

DOI: https://doi.org/10.31559/EPS2021.10.2.9 2021/6/20 2021/6/6 مراجعة البحث: 2021/6/15 قبول البحث:

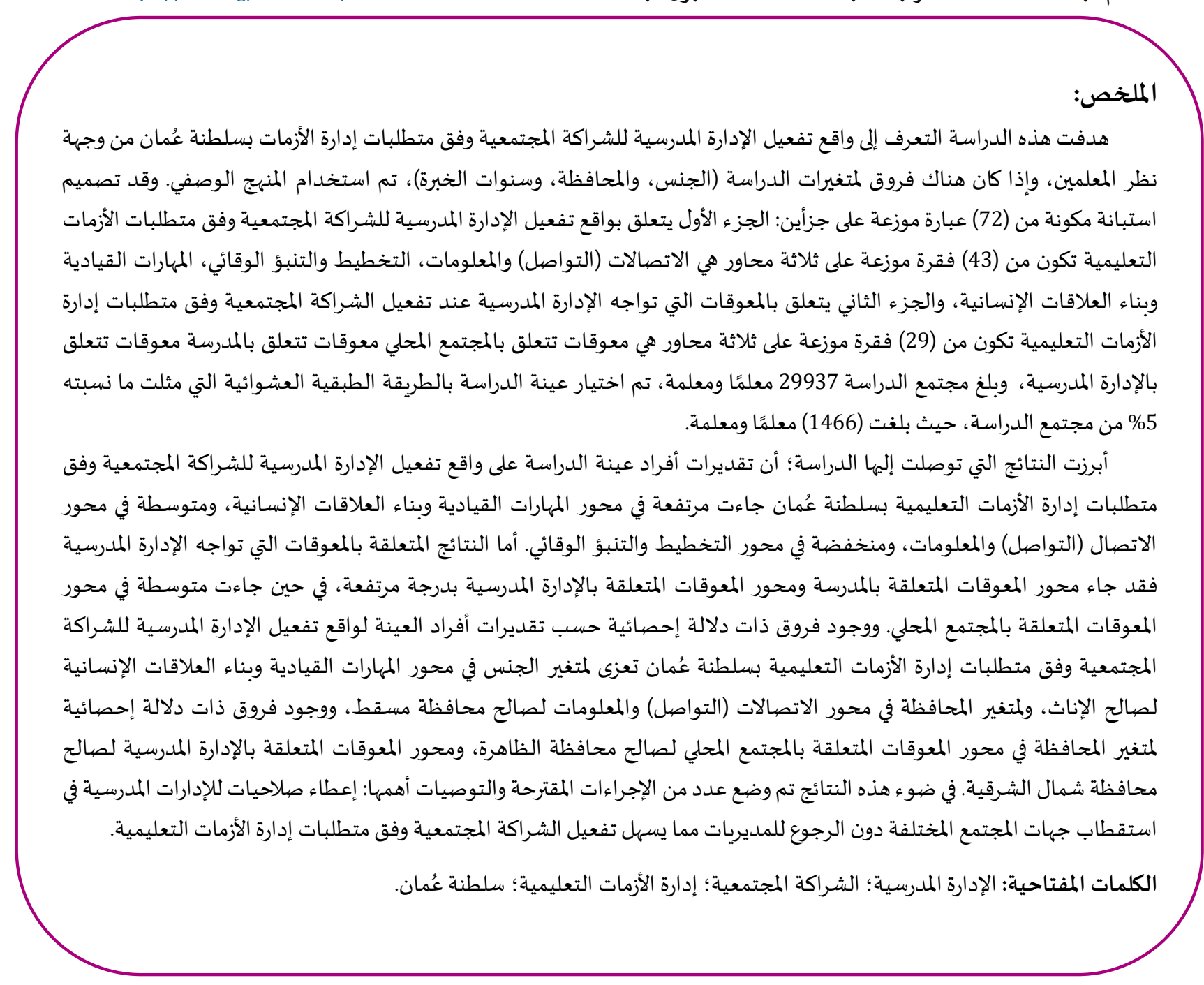




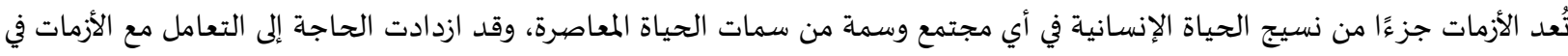

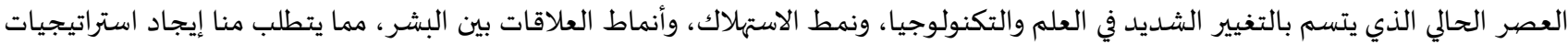

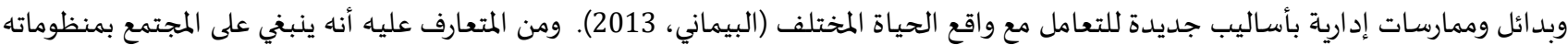

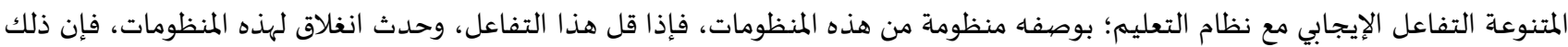

يؤدي حتمًا إلى حدوث الأزمة التعليمية. (صادق، 2003)

فالشراكة المجتمعية في العملية التعليمية ضرورة حتمية حتى تستطيع المدرسة أن تحقق أهدافها وطموحات مجتمعها خاصة وأن المدرسة

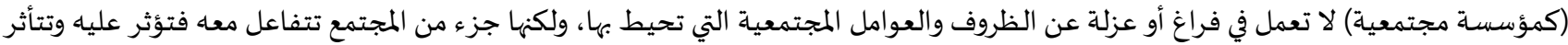

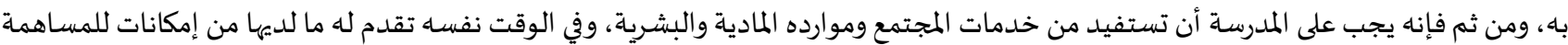

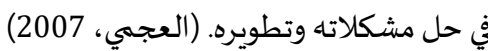

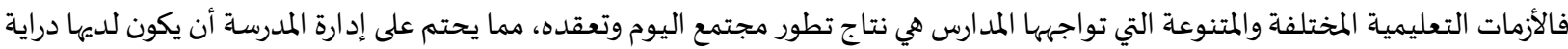

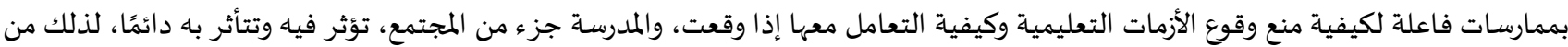

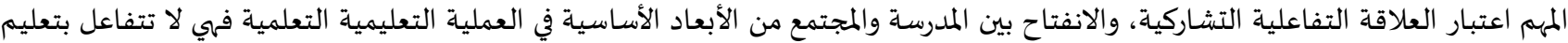

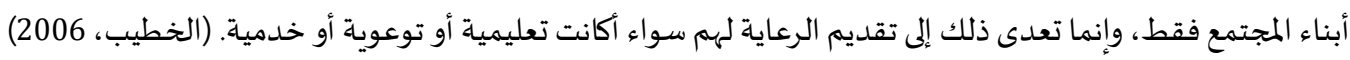

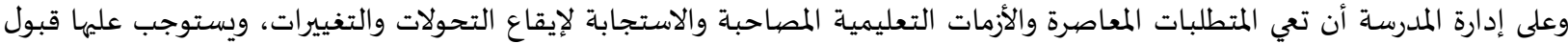

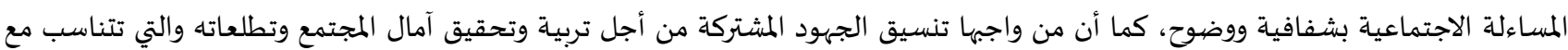

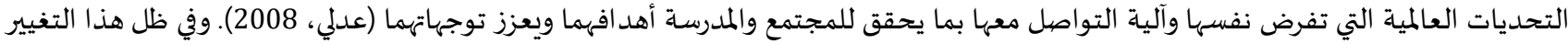
فإن الإدارة المدرسية سوف يكون لها أدوارها المتغيرة وممارساتها المتجددة باستمرار، وسوف يتطلب منها إيجاد وسائل وأساليب وممارسات مختلفة للشراكة والعلاقة بين المدرسة ومؤسسات المجتمع المختلفة. (Manasse, 2003)

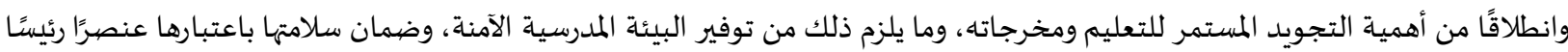

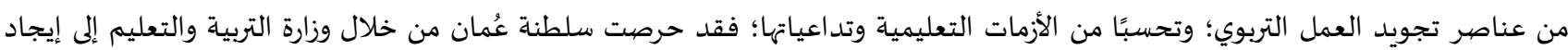

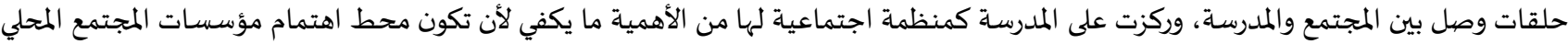

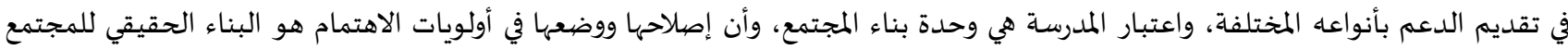
المحلي. (وزارة التربية والتعليم، 2002)

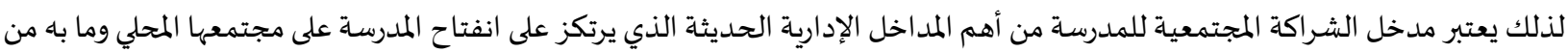

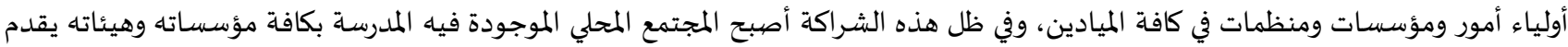

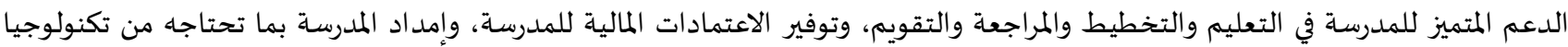

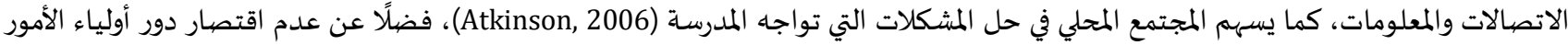

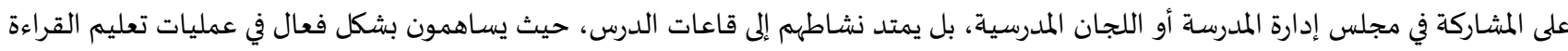

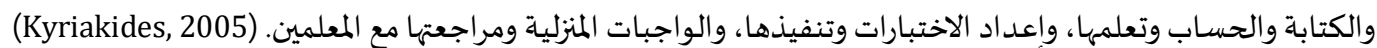

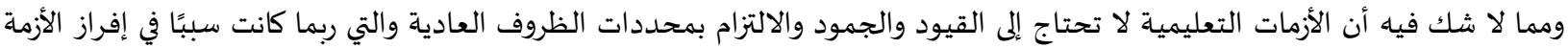

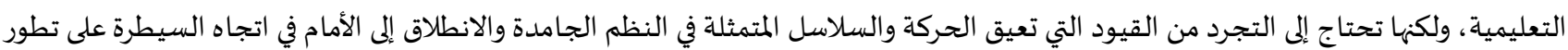

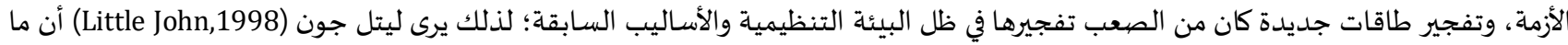

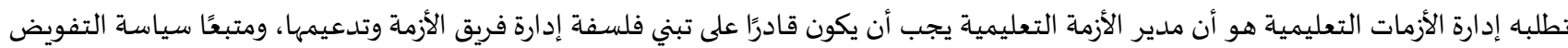

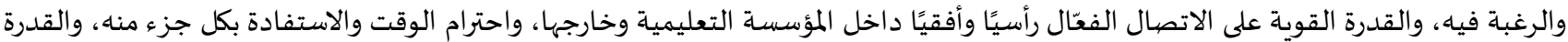

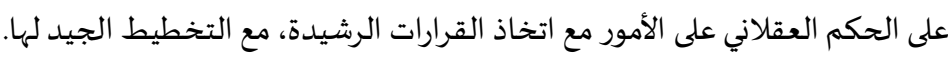

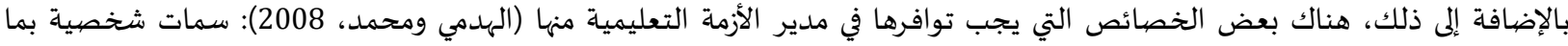

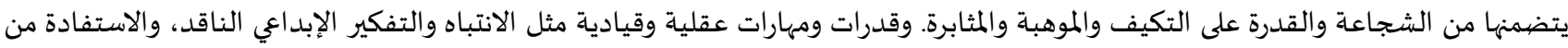

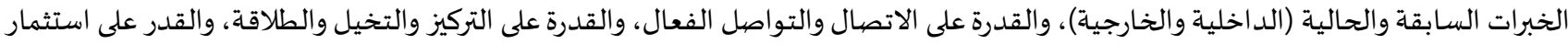

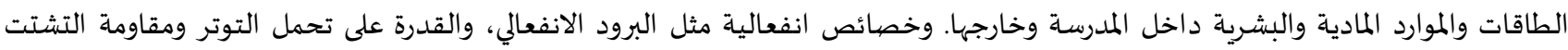

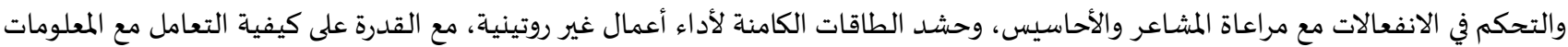
المتعلقة بالأزمة بسرية تامة. 
كما أن هناك متطلبات لا بد من توافرها والعمل بها في إدارة الأزمات التعليمية من أهمها: التخطيط لإدارة الأزمات التعليمياة: حيث يتم رسم

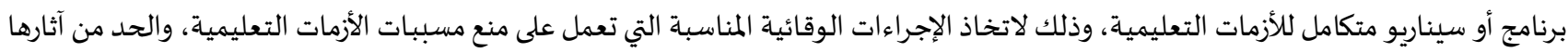

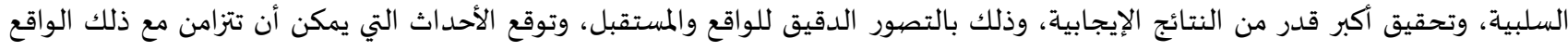

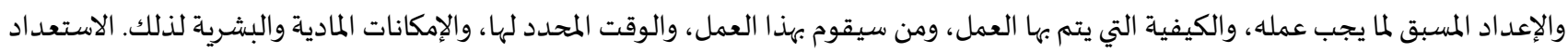
والوقاية التنبؤية: والهدف من الاستعداد والوقاية هو اكتشاف نقاط القوة والضعف ومعالجتها قبل أن تؤدي إلى ظهور الأزمة التعليمية وتناميها وتطورها، وتتمثل هذه المرحلة بالأنشطة الهادفة في تغطية الإمكانات والقدرات وتدريب الأفراد والمجمموعات على ولى كيفية التهاتية التعامل مع الأزمة التعليمية، فلا

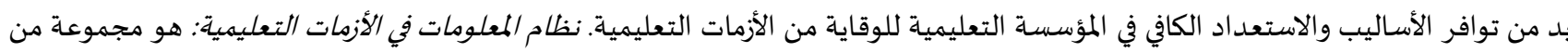

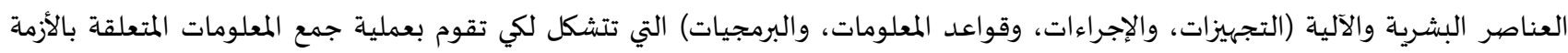

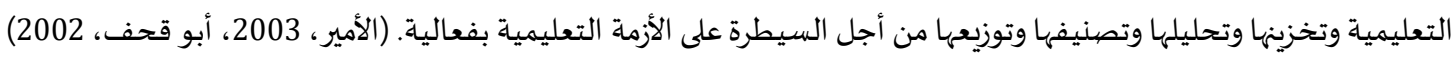

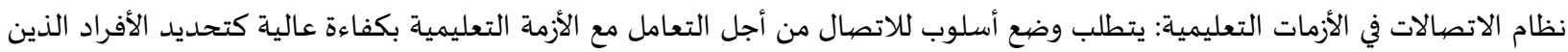

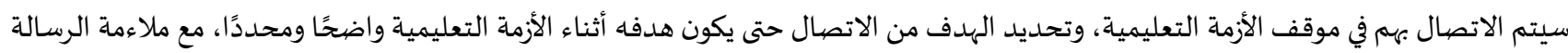

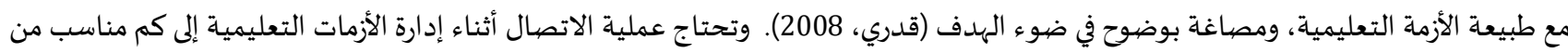

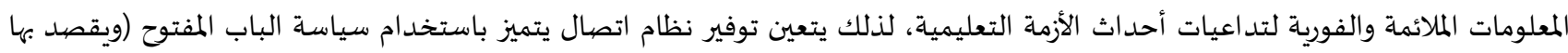

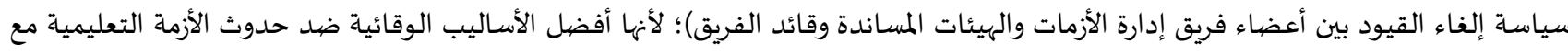

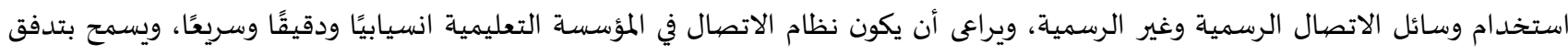

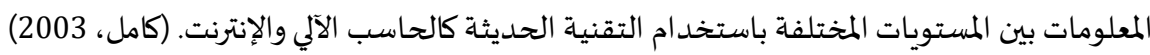
خلال إدارة الأزمات التعليمية لا بد من القيادة وعدم التجاهل ألمات الانشغال باستخد عن جات جانب العلاقات الإنسانية لما لها من دور مههم في التقليل من الآثار

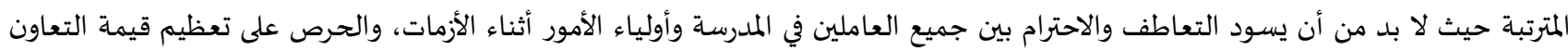

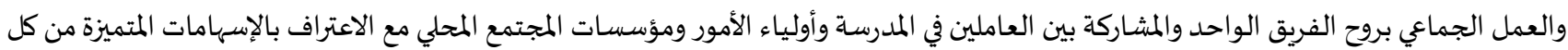

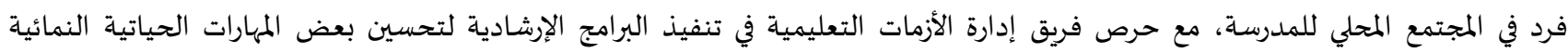

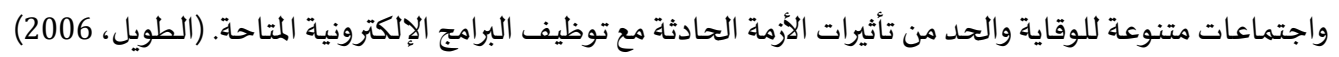
ويجب أن يدرك القائد دوره القيادي الأساسي الذي يكمن في توجياء العاملين معاه وإرشادهم وإثارة دافعيتهم وحفزهم وإثرائهم بالأفكار والبدائل

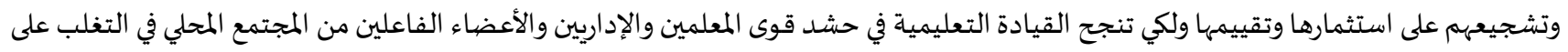

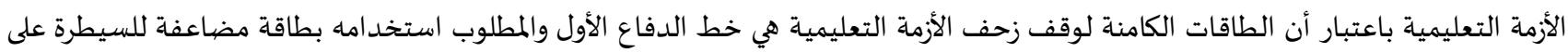

الأزمة التعليمية. (الطويل، 2006) الازمة التعبية باعتبار ان الطبات

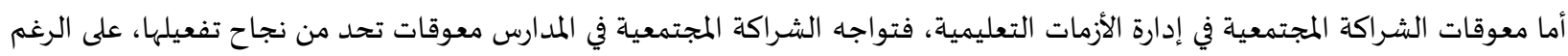
من التأكيد على أهمية وجود علاقة قوية وتعاون بين المدرسة والمجتمع من أجل ضمات إدان تحقيق العملية التعليمية لأهدافها وضمانمان التنشئة الاجتماعية

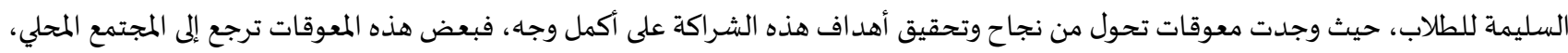

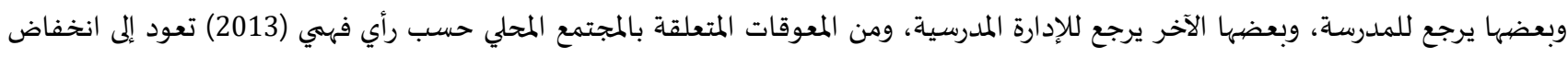

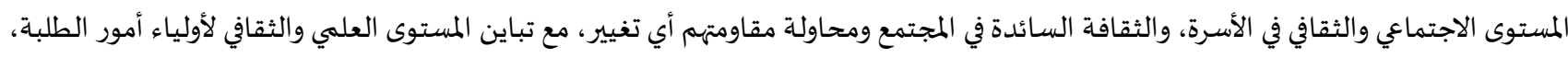
والخوف لدى أفراد المجتمع المحلي من تبعات الشراكة مع المدرسة في اتخاذ القرار، وأضاف لذلك حمدونة والكانة (2006) اعتقاد المجتمع المحلي بأن التعليم

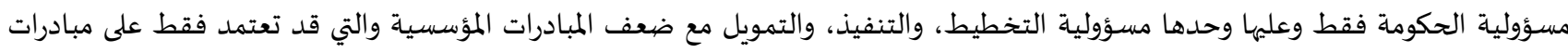

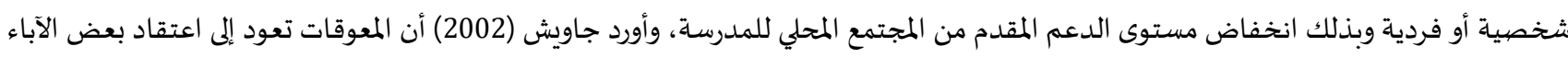

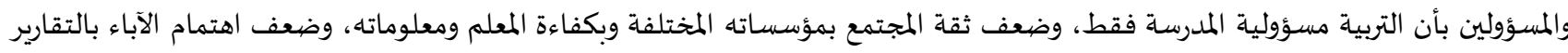

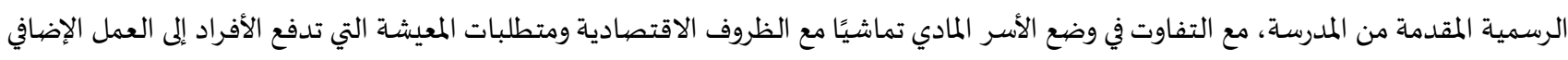

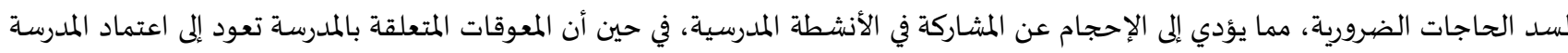

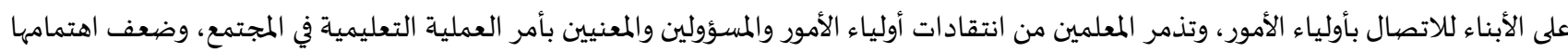

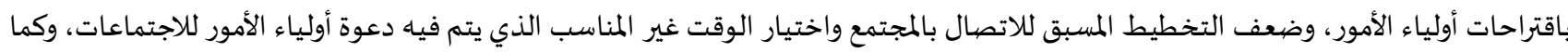

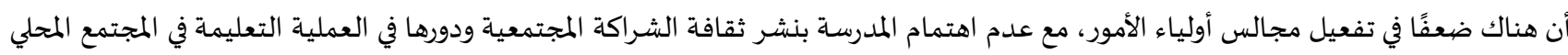
(الصوافية، 2008). بينما ذكر ضحاوي وعبدالعزيز(1998) أن معوقات الشراكة المجتمعية للإدارة المدرسية تعود إلى إغفال الإدارة المدرسية لأهمية

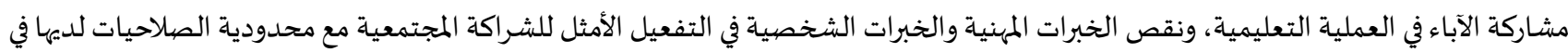

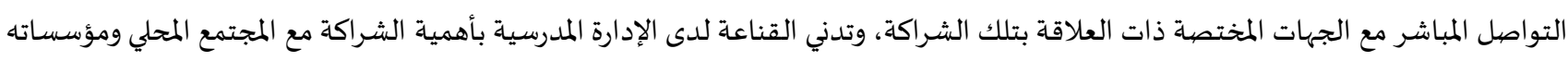




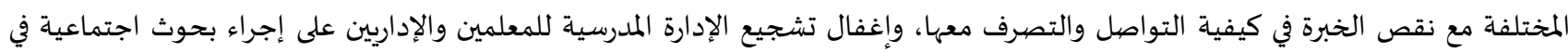

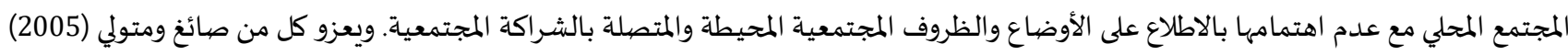

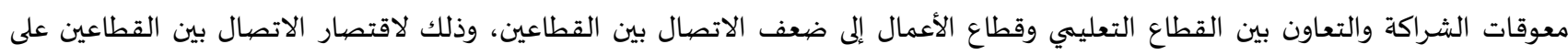

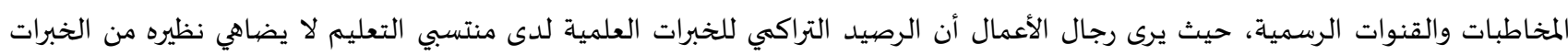

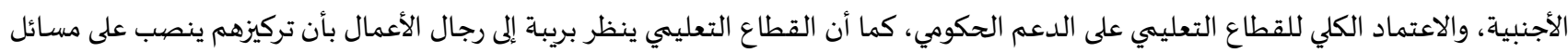

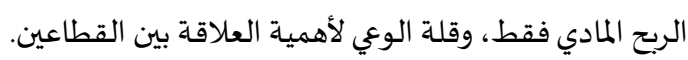

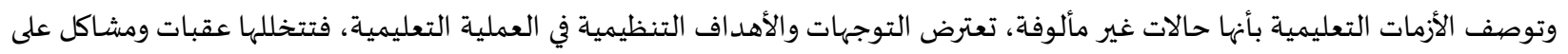

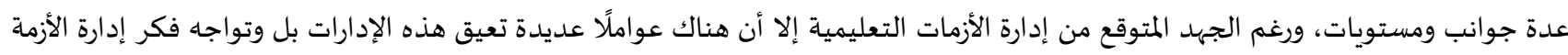

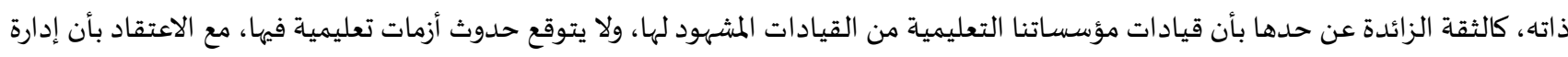

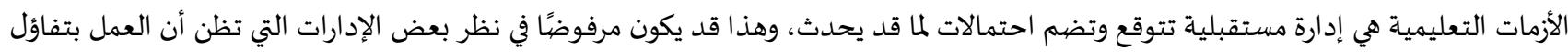

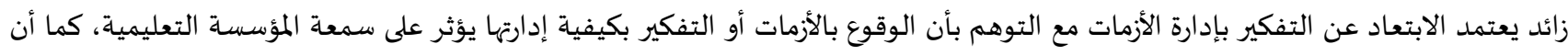

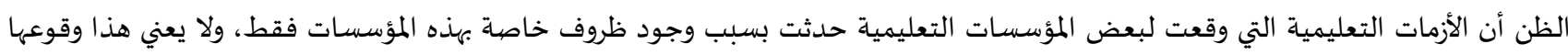

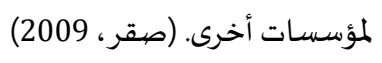

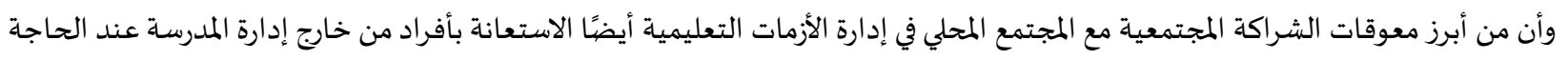

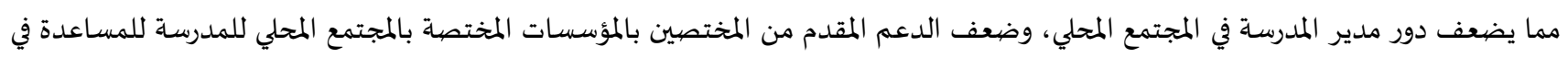

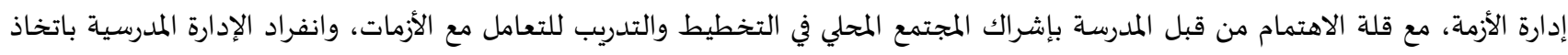

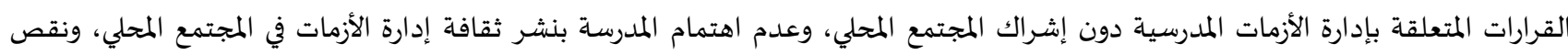

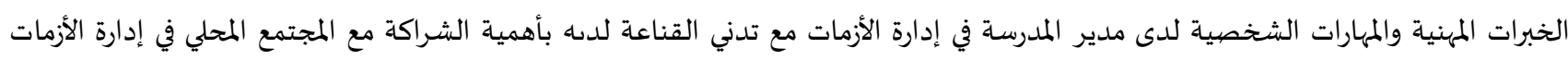

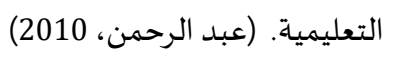

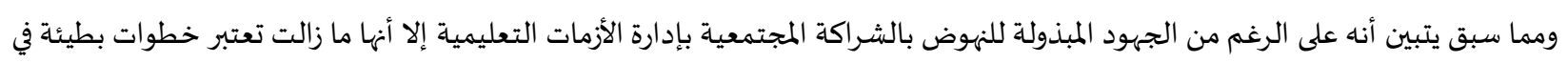

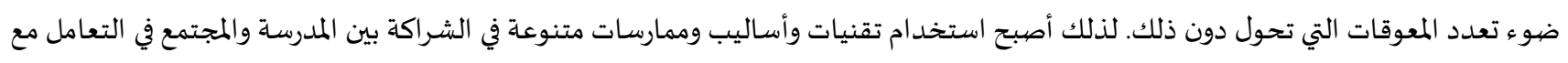

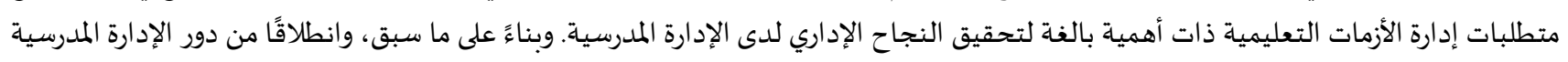

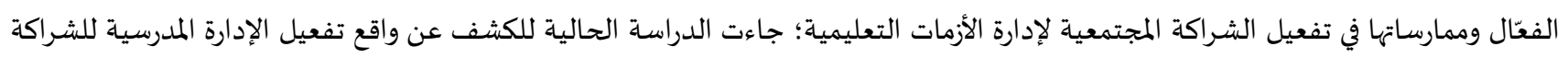
المجتمعية وفق متطلبات إدارة الأزمات التعليمية بسلطنة عُمان.

1.1. مشكلة الدراسة:

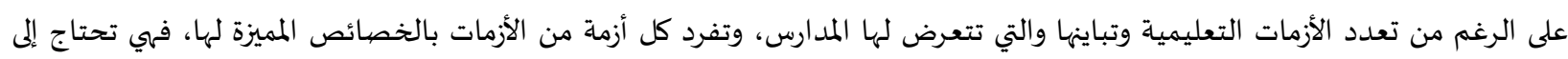

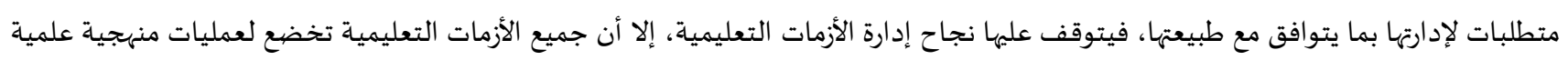
مشتركة في إدارتها، لتجنب وقوعها والتخفيف من نتائجها.

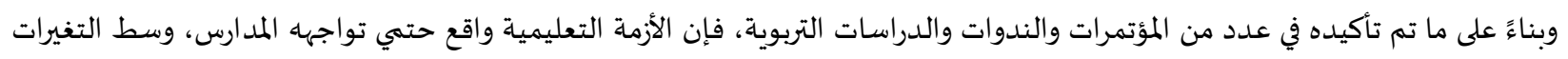

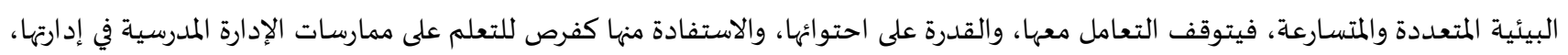

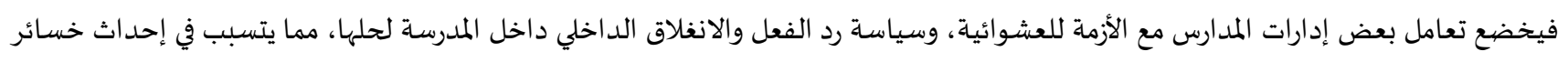

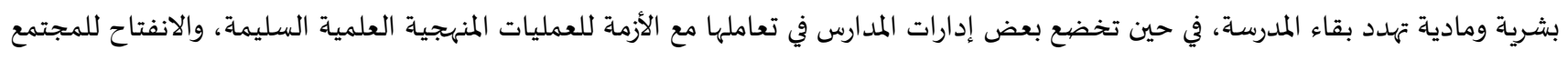

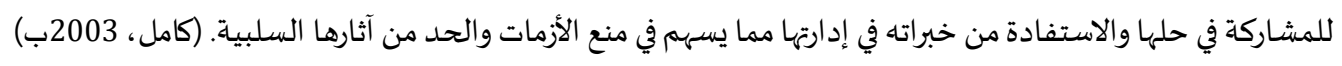

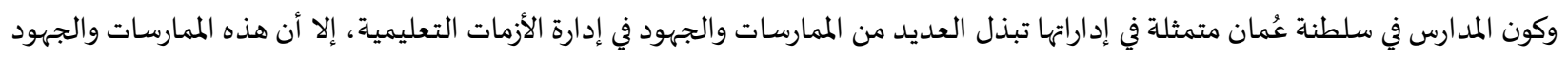

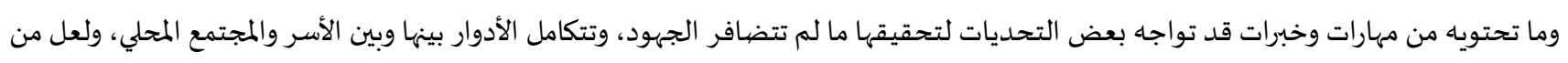

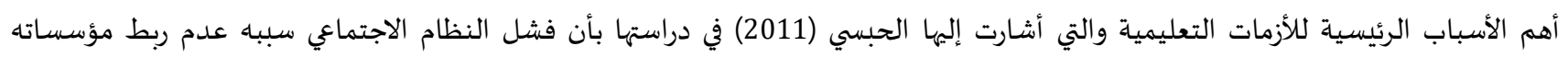

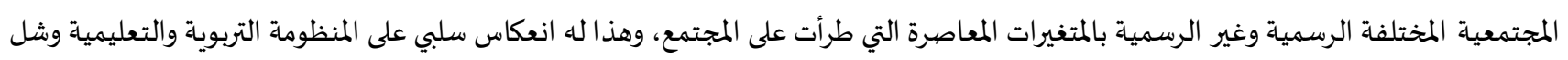

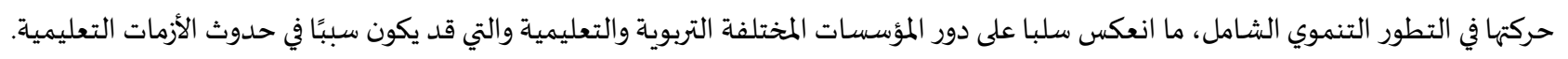

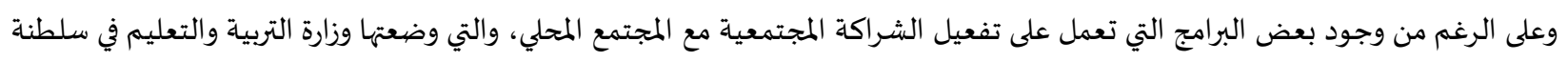

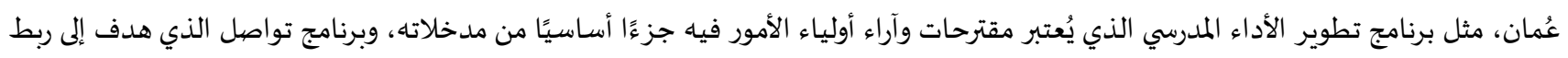

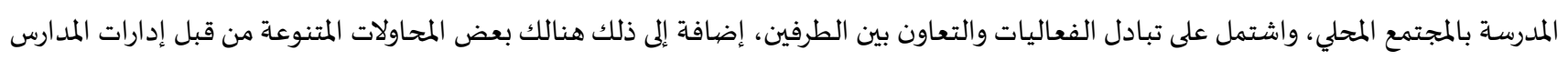




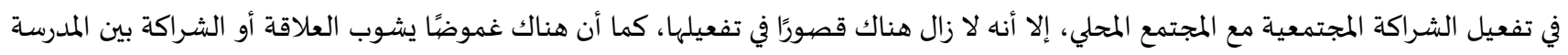

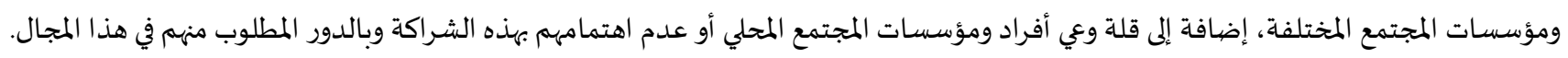

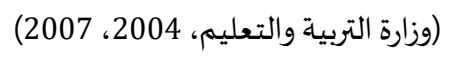
وأكدت ذلك عدة دراسات، كدراسة الزاملي وآخرين (2007) حيث أشارت إلى وجود ضعات التهف في الأساليب والممارسات التي تستخدمها الإدارات

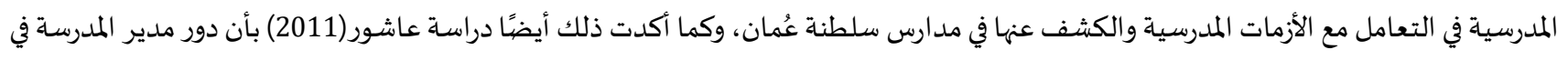

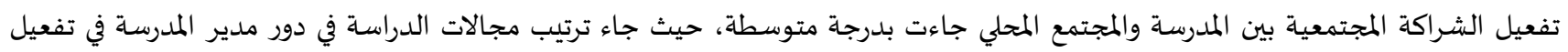

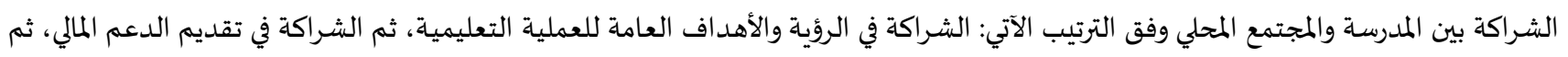

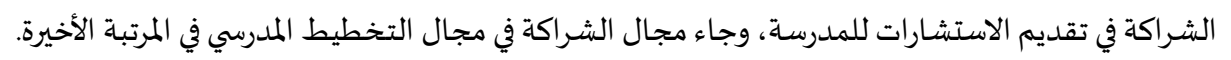

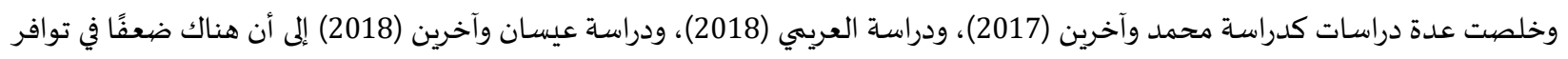

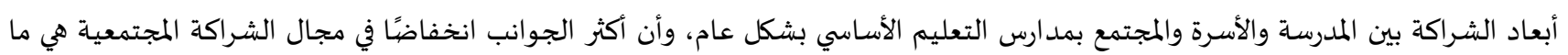

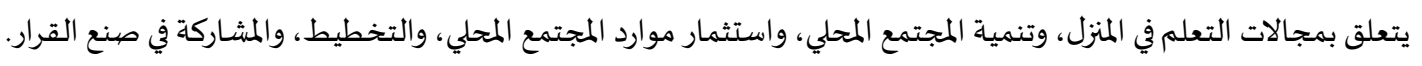

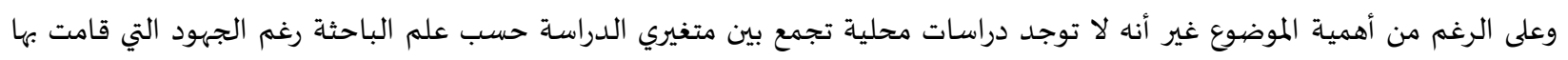

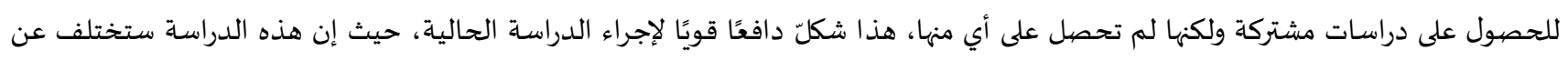

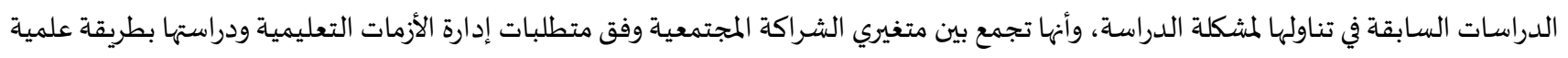

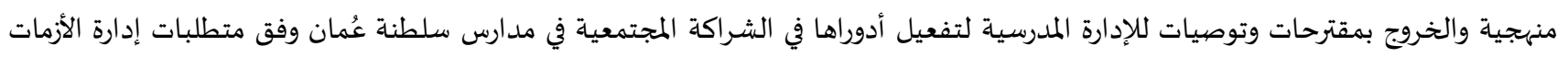

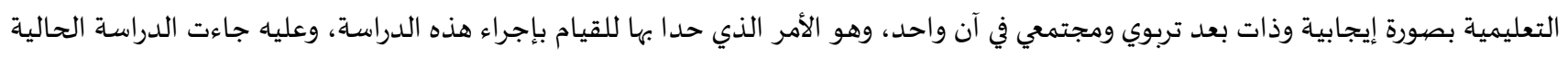

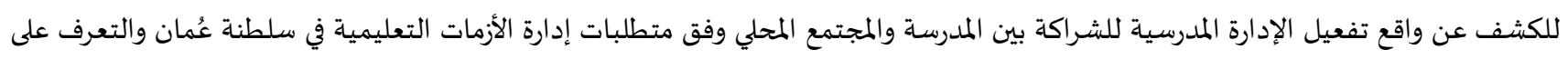
المعوقات التي تحول دون تفعيل هذه الشراكة.

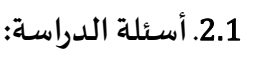

تحاول الدراسة الإجابة عن الأسئلة الآتية:

1.

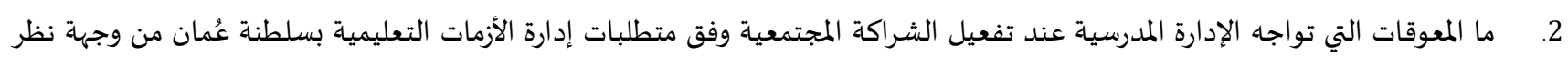

المعلمين؟

3. هل توجد فروق ذات دلالة إحصائية بين استجابات عينة الدراسة حول واقع تفعيل الشراكة المجتمعية وفق متطلبات إدارة الأزمات التعليمية

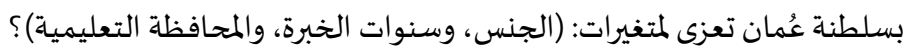

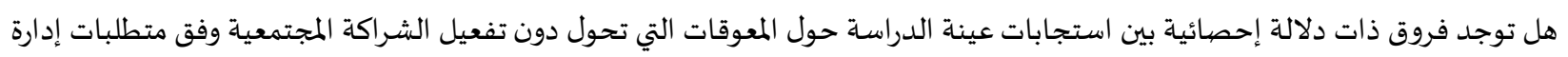
الأزمات التعليمية بسلطنة عُمان تعزى لمتغيرات: (الجنس، وسنوات الخبات الخبرة، والمحافظة التعليمية)؟

3.1 أهداف الدراسة:

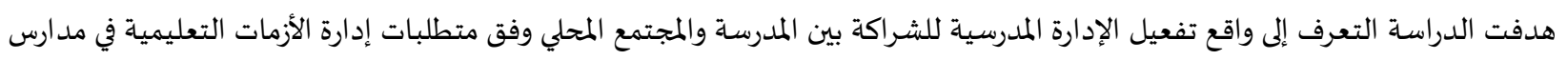

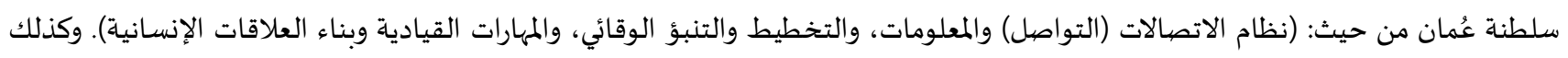

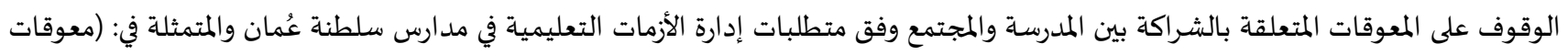

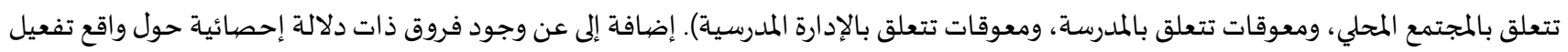

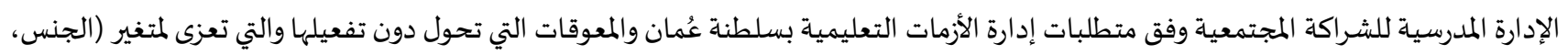

وسنوات الخبرة، والمحافظة التعليمية).

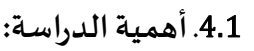

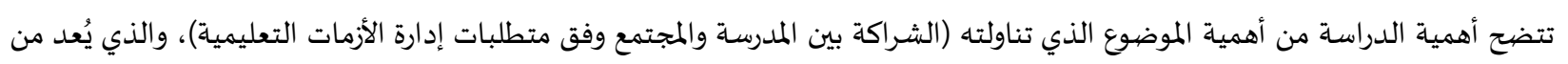

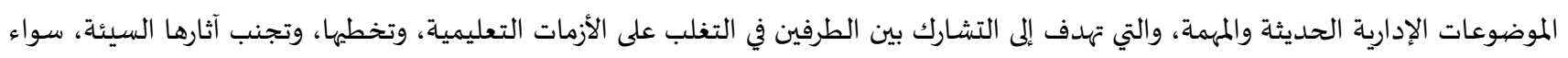
على المدى القريب أو البعيد.

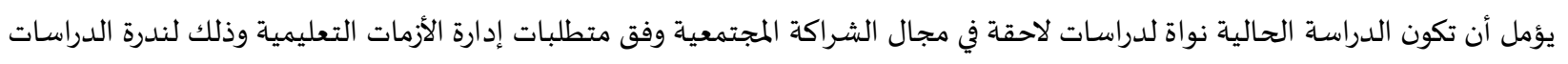

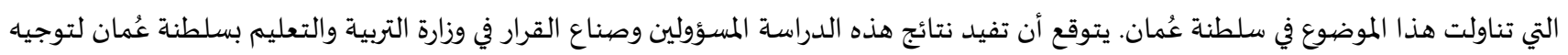

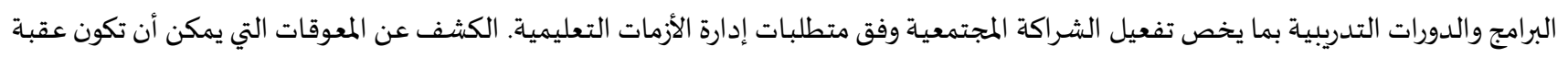


في تفعيل الشراكة المجتمعية بين المدرسة ومؤسسات المجتمع المحلي وفق متطلبات إدارة الأزمات التعليمية، فإن نتائج هذه الدراسة تقدم تقييما واقعيًا

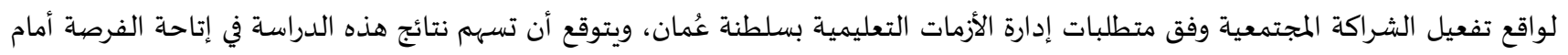

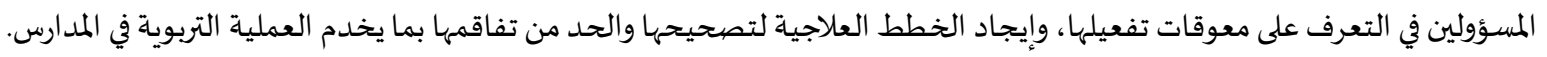

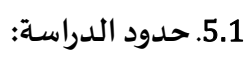

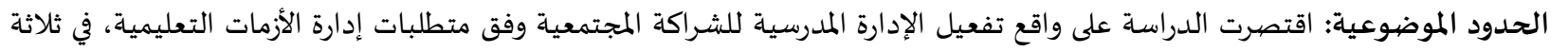

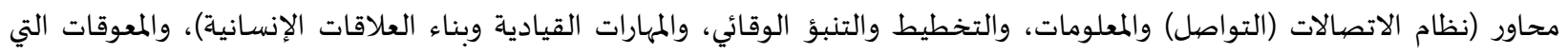

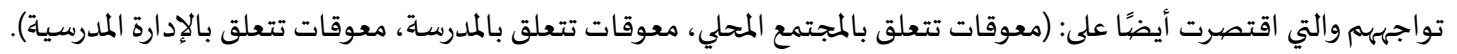

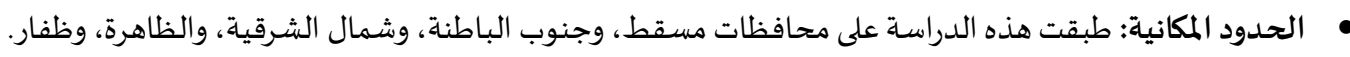

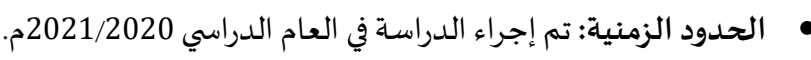
• الحدود البشرية: اقتصرت الدراسة على فئة المعلمين والمعلمات.

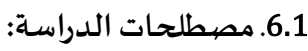

• إدارة الأزمات التعليمية: "كيفية التغلب على الأزمة بالأدوات العلمية الإدارية المختلفة وتجنب سلبياتها، والاستفادة من إيجابياتها، ولذلك فهي

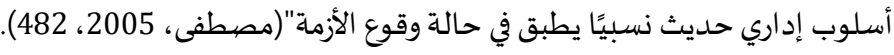

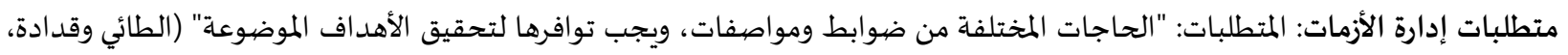

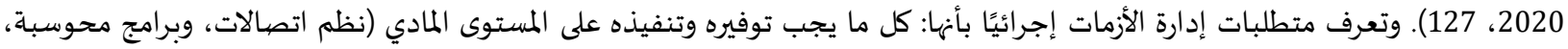

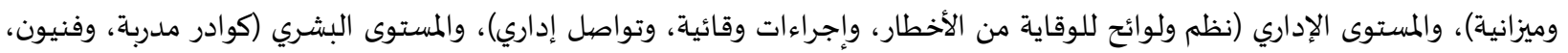
ومختصون) من أجل تأكيد نجاح إدارة الأزمات التعليمية في المدارس.

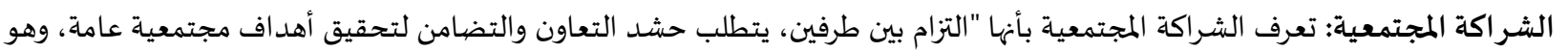

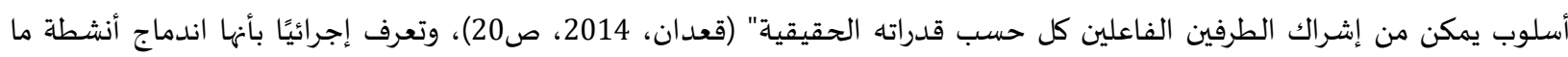

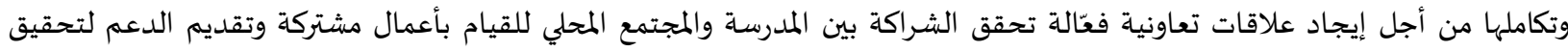
مجموعة من الغايات والأهداف في تطوير العملية التعليمية.

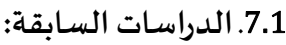
اهتم العديد من الباحثين بالشراكة المجتمعية وإدارة الازمات على المستويين العربي والعالمي؛ فيما بحثت دراسات أخرى في متطلبات إدارة الأزمات التعليمية ودعت إلى تفعيل العلاقة بين المدرسة والمجتمع، ومن بينها:

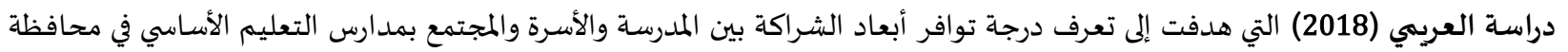

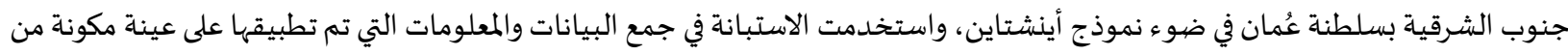

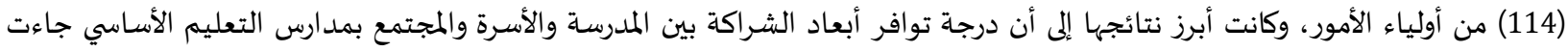

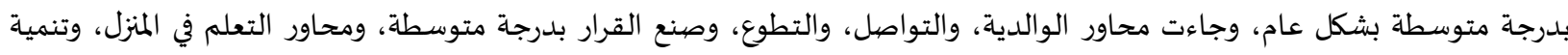

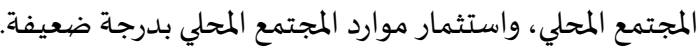

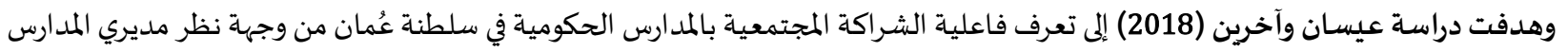

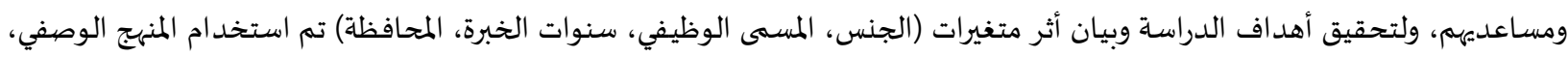

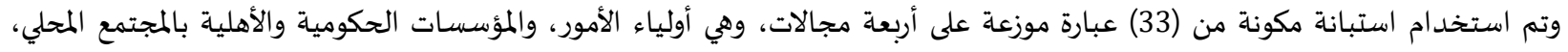

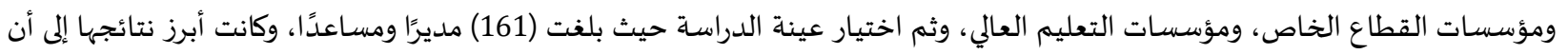

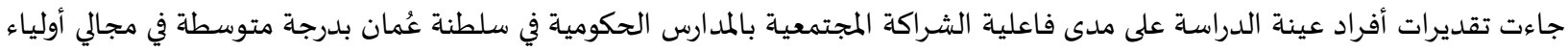

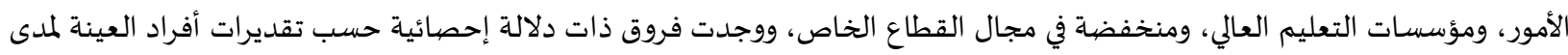

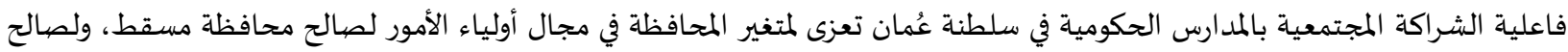

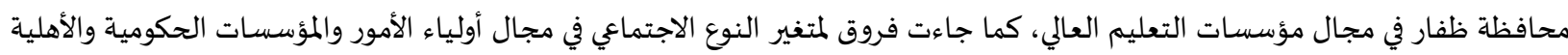

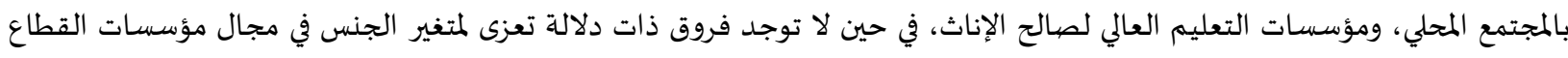

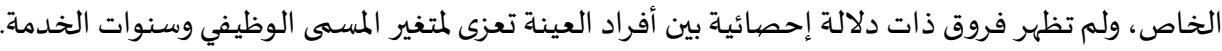


وكما ركزت دراسة النوح (2019) التي هدفت إلى تعرف دور إدارة المدرسة في تفعيل الشراكة مع المجتمع المحلي كما يراها مديرو المدارس الثانوية

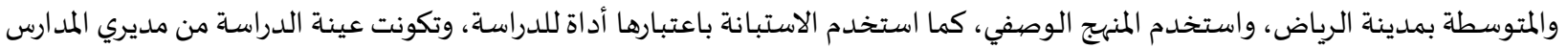

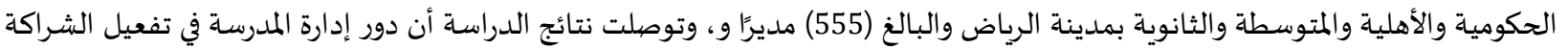
مع المجتمع المحلي جاءت بدرجة متوسطة وقريبا من الدرجة الضعيفة، أما أهمية الدور فجاء بدرجة عالية. وأن المعوقات التي تواجه إدارة

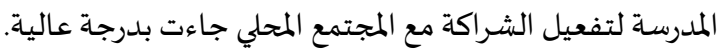
أما دراسة القحطاني (2019) التي ركزت إلى الكشف عن ممارسات مديرات المدارس لعمليات إدارة الأزمات من حيث: التخطيط للأزمات،

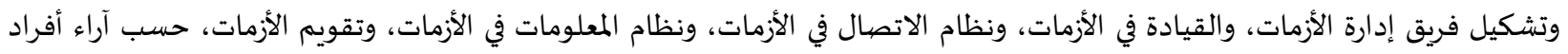

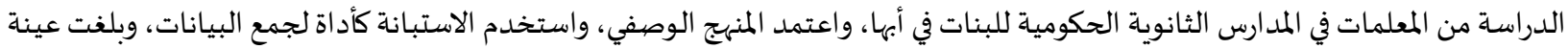

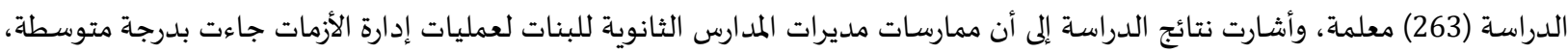

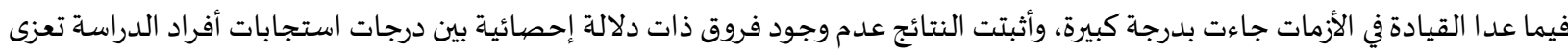

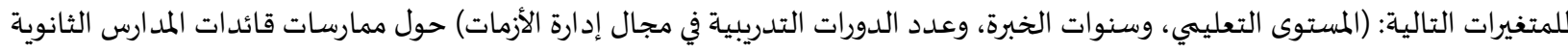
بمدينة أبها لإدارة الأزمات.

وأجرى الظفر والعمود (2019) دراسـة هدفت إلى الكشف عن واقع تطبيق الصلاحيات المتعلقة بإدارة الأزمات الممنوحة لمديرات المرحلة

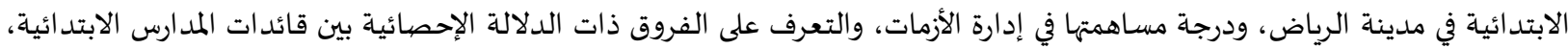

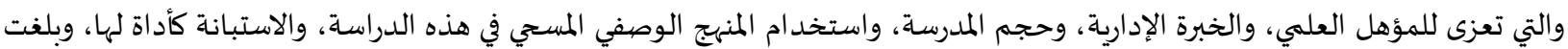

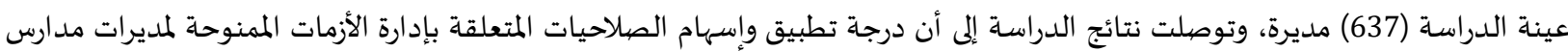

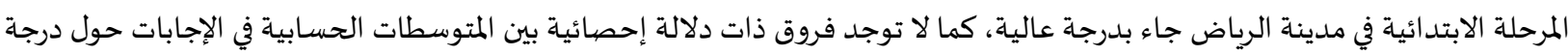

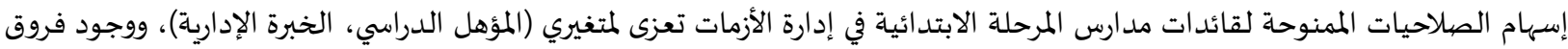
ذات دلالة إحصائية بين المتوسطات الحسابية في الإجابات حول درجة إسهام الصاتلاحيات الممنوحة لقائدات المات مدات مدارس المرحلة الابتدائية في إدارة الأزمات تعزى لمتغير حجم المدرسة.

دراسة الزاملي وآخرون (2007) التي هدفت إلى الكشف عن الأزمات المدرسية وأساليب التعامل معها في مدارس سلطنة عُمان والتعرف على

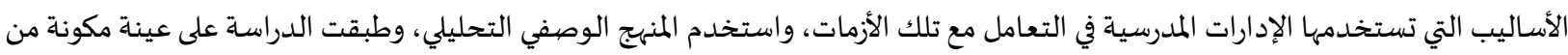

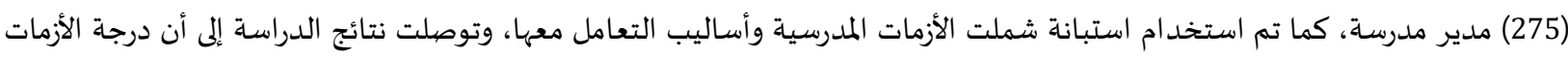
المدرسية من وجهة نظر مديري المدارس جاءت ملدير مدرسة، بدرة متوسطة. وحازت الأزمات المتعلقة بالطلبة على المرتبة الأولى، تلهيها الأزمات المتعلقة بالإدارة،

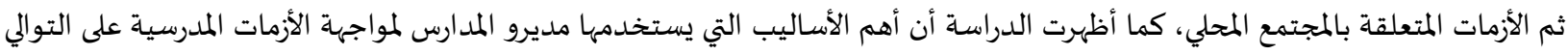

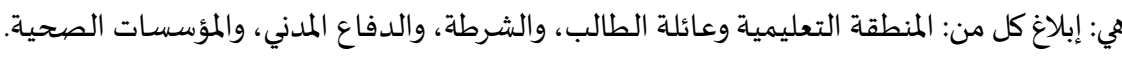
وكما هدفت أيضًا دراسة العينبوسي وسليمات (2007) إلى الكشف عن الأزمات المدرسية التي تتعرض لها مدارس سلطنة عُمان من وجهة نظر

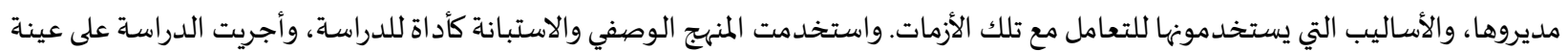

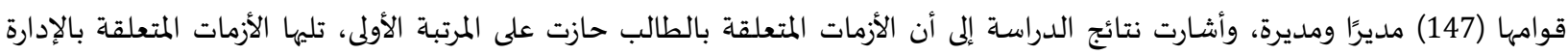

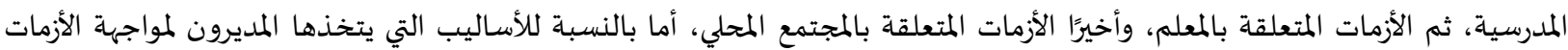
فلوحظ وجود ضعف في قدراتهم على حل الأزمات على مستوى المدرسة، إلا في حالات قليلة في مجال المعلم والمجتمع المحلي.

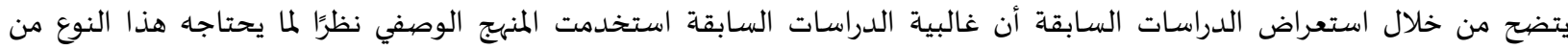

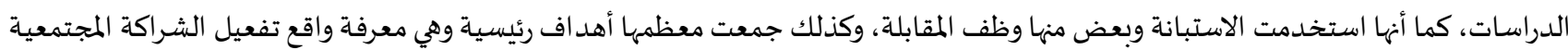

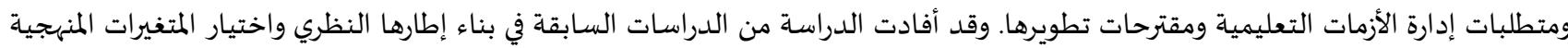

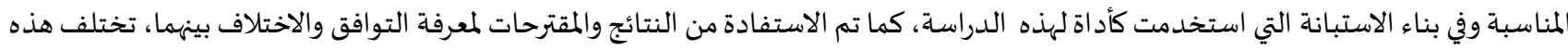
الدراسة عن بقية الدراسات بأها سوف تدرس واقع تفعيل الإدارة المدرسية للشراكة المجتمعية وفق متطلبات إدارة الأزمات التعليمية بسلطنة عُمانان،

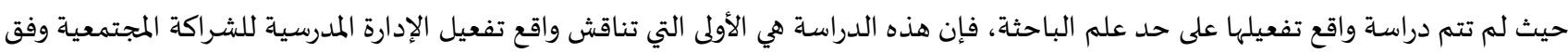
متطلبات إدارة الأزمات بسلطنة عُمان. 
2. 2 2 الطريقة والإجراءات:

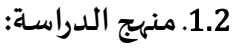

اعتمدت الدراسة المنهج الوصفي لملاءمته لطبيعة وأهداف الدراسة، وانطلاقًا من مشكلة الدراسة وطبيعة تساؤلاتها، وذلك من خلال استخدام الاستبانة أداةً، حيث تم إخضاعها لاختبارات الصداسق والثنبات.

2.2. 2.2 مجتمع الدراسة وعينتها:

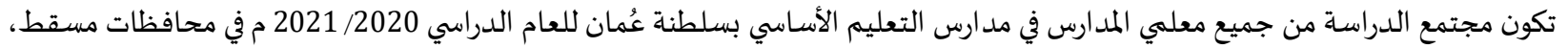

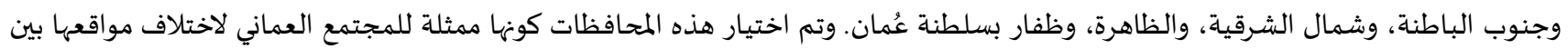

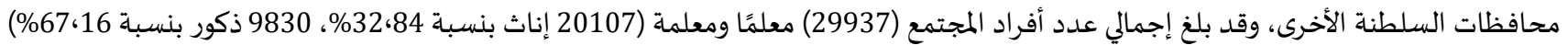

(وزارة التربية والتعليم، 2020).

بينما تكونت عينة الدراسة من (1497) معلمًا ومعلمة، بواقع (5\%) من مجتمع الدراسة، تم اختيارهم بالطريقة الطبقية العشوائية، وكان العائد العيدات من العينة 1466 والجدول (1) يوضح توزيع أفراد عينة الدراسة حسب متغير الجنس وسنوات الخبرة الخبات والمحافظة التعليمية.

\begin{tabular}{|c|c|c|c|c|c|c|c|}
\hline \multirow[t]{3}{*}{ المجموع } & \multicolumn{4}{|c|}{ المححافظــــة التعليمية } & & \multirow[t]{3}{*}{ الجنس } & \multirow[t]{3}{*}{ سنوات الخبرة } \\
\hline & \multirow[t]{2}{*}{ ظفار } & \multirow[t]{2}{*}{ الظاهرة } & \multirow{2}{*}{ شمال } & \multirow{2}{*}{ جنوب الباطنة } & \multirow[t]{2}{*}{ مسقط } & & \\
\hline & & & & & & & \\
\hline 190 & 22 & 36 & 17 & 29 & 86 & ذكور & أقل من 5 سنوات \\
\hline 246 & 35 & 40 & 43 & 81 & 47 & إناث & \\
\hline 148 & 49 & 18 & 10 & 27 & 44 & ذ ذكور & من 5 - 10 سنوات \\
\hline 380 & 71 & 48 & 50 & 100 & 111 & إناث & \\
\hline 133 & 23 & 15 & 19 & 34 & 42 & ذ ذكور & أكثر من 10 سنوات \\
\hline \multirow[t]{2}{*}{369} & 75 & 30 & 71 & 76 & 117 & إناث & \\
\hline & 1466 & 275 & 187 & 210 & 347 & 447 & المجموع \\
\hline
\end{tabular}

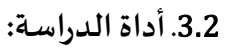

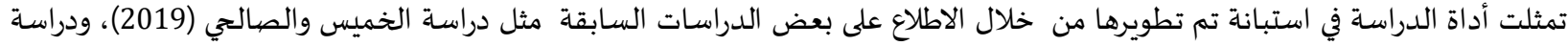
السبيعي وسنبل (2019)، ودراسة القحطاني (2019)، ودراسة محمد (2019)، ودراسة العبدالله (2019)، ودراسة عيسان والخدان الخنبشية (2018)،

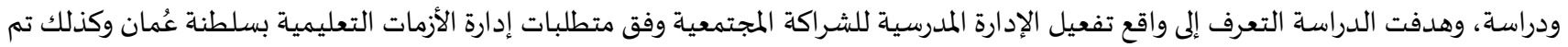

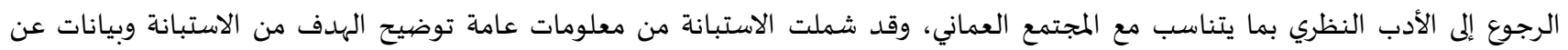

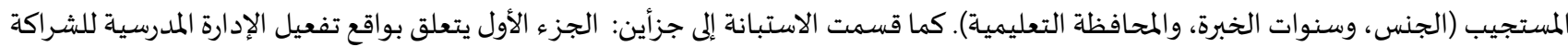

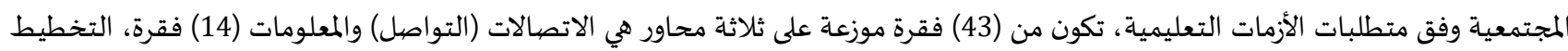

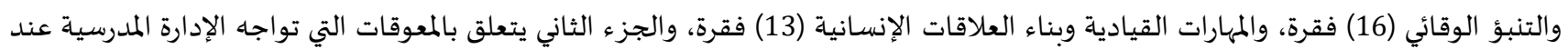

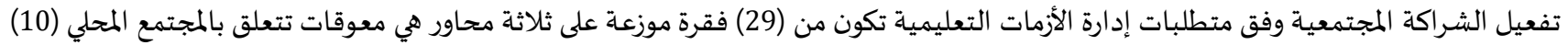

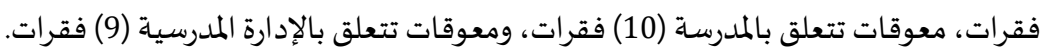

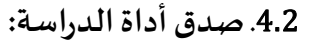

تم التحقق من الصدق الظاهري أو ما يعرف بصدق المحكمين للأداة عن طريق عرضها على الى (20) محكمًا من المختصين في مجال التربية في كل من

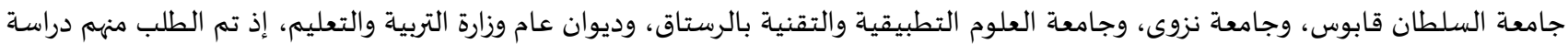

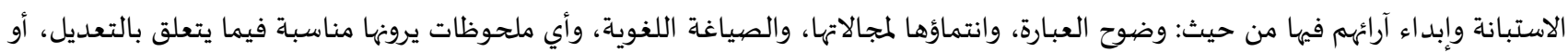

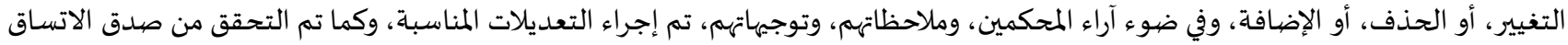

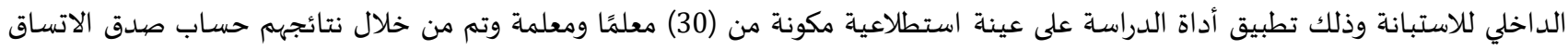

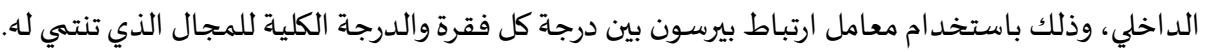




\begin{tabular}{|c|c|c|c|c|c|c|c|}
\hline الارتباط معامل & والعبارات & الارتباط معامل & المحاوروالعبارات & الارتباط معامل & والعبارات & الارتباط & 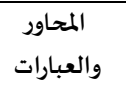 \\
\hline$* 0 ، 829$ & & & & & \multicolumn{3}{|c|}{ المححور الأول " نظام الاتصالات (التواصل) والمعلومات " } \\
\hline$* 0 ، 618$ & 4 & $* 0 ، 821$ & 3 & $* 0,653$ & 2 & $* 0.732$ & 1 \\
\hline$* 0 ، 797$ & 8 & $* 0 ، 635$ & 7 & $* 0 ، 432$ & 6 & $* 0 ، 767$ & 5 \\
\hline$* 0 ، 605$ & 12 & $* 0 ، 659$ & 11 & $* 0 ، 825$ & 10 & $* 0 ، 803$ & 9 \\
\hline$* 0 ، 719$ & 16 & $* 0 ، 668$ & 15 & $* 0 ، 826$ & 14 & $* 0 ، 773$ & 13 \\
\hline$* 0 ; 502$ & & & & & \multicolumn{3}{|c|}{ المحور الثاني " التخطيط والتنبؤ الوقائي" } \\
\hline$* 0.677$ & 4 & $* 0.763$ & 3 & $* 0.665$ & 2 & $* 0.732$ & 1 \\
\hline$* 0 ، 603$ & 8 & $* 0.679$ & 7 & $* 0.513$ & 6 & $* 0.555$ & 5 \\
\hline \multirow[t]{2}{*}{$* 0 ، 720$} & 12 & $* 0 ، 812$ & 11 & $* 0 ، 575$ & 10 & $* 0 ، 681$ & 9 \\
\hline & & & & & & $* 0 ، 601$ & 13 \\
\hline$* 0 ; 759$ & & & & & \multicolumn{3}{|c|}{ المححور الثالث: " المهارات القيادية وبناء العلاقات الإنسانية" } \\
\hline$* 0.689$ & 4 & $* 0.711$ & 3 & $* 0.652$ & 2 & $* 0.785$ & 1 \\
\hline \multirow[t]{2}{*}{$* 0.734$} & 8 & $* 0.811$ & 7 & $* 0.796$ & 6 & $* 0.775$ & 5 \\
\hline & & & & $* 0 ، 849$ & 10 & $* 0 ، 637$ & 9 \\
\hline$* 0,732$ & & & & & \multicolumn{3}{|c|}{ المحور الر ابع: "معوقات تتعلق بالمجتمع المحلي } \\
\hline$* 0.821$ & 4 & $* 0.763$ & 2 & $* 0.655$ & 2 & $* 0.739$ & 1 \\
\hline \multirow[t]{2}{*}{ *0.716 } & 8 & $* 0.672$ & 7 & $* 0.803$ & 6 & $* 0.657$ & 5 \\
\hline & & & & $* 0 ، 754$ & 10 & $* 0 ، 620$ & 9 \\
\hline$* 0 ; 705$ & & & & & \multicolumn{3}{|c|}{ المحور الخامس: "معوقات تتعلق بالمدرسة" } \\
\hline$* 0.774$ & 4 & $* 0.829$ & 3 & $* 0.792$ & 2 & $* 0.669$ & 1 \\
\hline \multirow[t]{2}{*}{$* 0.747$} & 8 & $* 0.803$ & 7 & $* 0.756$ & 6 & $* 0.626$ & 5 \\
\hline & & & & & & $* 0.458$ & 9 \\
\hline${ }^{* 0} 0.689$ & & & & & \multicolumn{3}{|c|}{ المحور السادس: "معوقات تتعلق بالإدارة المدرسية" } \\
\hline$* 0.824$ & 4 & $* 0.774$ & 3 & $* 0.742$ & 2 & $* 0.680$ & 1 \\
\hline$* 0.795$ & 8 & $* 0.743$ & 7 & $* 0.782$ & 6 & $* 0.680$ & 5 \\
\hline \multirow[t]{2}{*}{$* 0,813$} & 12 & $* 0.676$ & 11 & $* 0,686$ & 10 & $* 0.814$ & 9 \\
\hline & & & & $* 0.691$ & 14 & $* 0,797$ & 13 \\
\hline
\end{tabular}

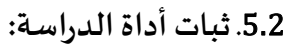

تم التحقق من الثبات باستخدام معادلة ألفا كرونباخ لجميع المحاور وللاستبانة ككل، حيث بلغ معامل الاتساق الداخلي للاستبانة ككل (0.833) وتعتبر هذه القيمة جيدة في مقاييس العلوم الإنسانية وتعتبر الأداة ثابتة وصالحة للتطبيق.

3.

1.3. النتائج المتعلقة بالسؤال الأول: ما و اقع تفعيل الإدارة المدرسية للشر اكة المجتمعية وفق متطلبات إدارة إلتارة الأزمات التعليمية؟

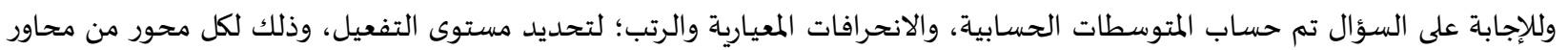
الأداة والدرجة الكلية، والجدول (3) يوضح ذلك. جدول (3): المتوسطات الحسابية والانحر افات المعيارية لتقديرات أفراد عينة الدراسة حول و اقع تفعيل الإدارة المدرسية للشر اكة المجتمعية وفق متطلبات الأزمات التعليمية ورتبها والدرجة الكلية

\begin{tabular}{|c|c|c|c|c|c|}
\hline درجة التفعيل & 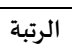 & الانحراف المعياري & المتوسط الحسابي & المحاور & م \\
\hline متوسطة & 2 & 0,20 & 3.02 & الاتصالات (التواصل) والمعلومات & 1 \\
\hline منخفضية & 3 & 0,23 & 2,22 & التخطيط والتنبؤ الوقائي & 2 \\
\hline 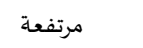 & 1 & 0,25 & 3,54 & المهارات القيادية وبناء العلاقات الإنسانية & 3 \\
\hline متوسطة & & 0,10 & 3.22 & الدرجة الكلية & \\
\hline
\end{tabular}


يتضح من الجدول (3) أن المتوسط الحسابي للدرجة الكلية لواقع تفعيل الإدارة المدرسية للشراكة المجتمعية وفق متطلبات إدارة الأزمات

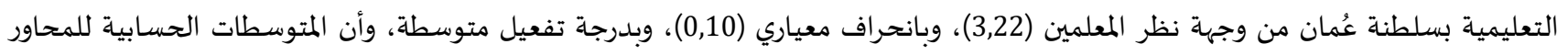

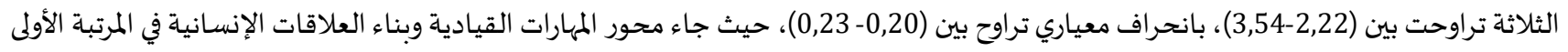

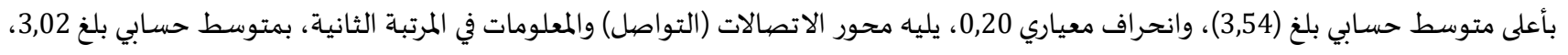

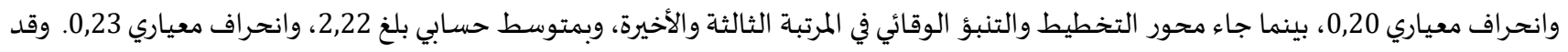

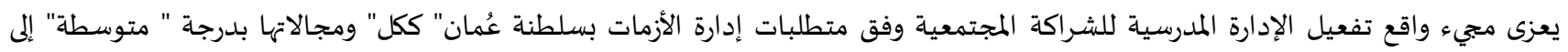

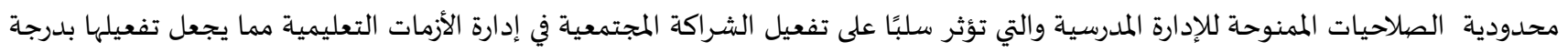

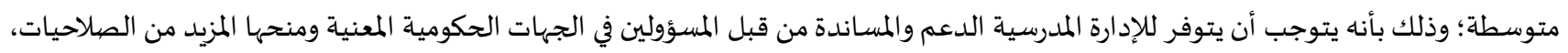

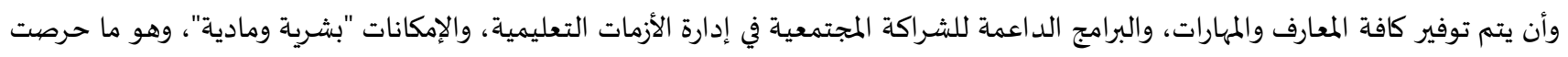

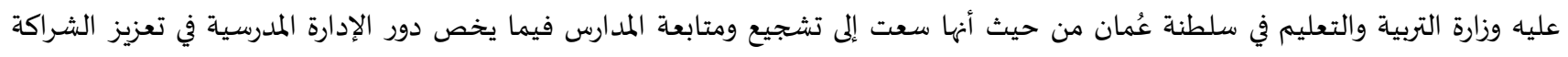

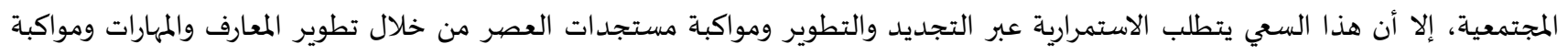

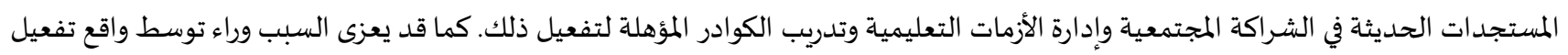

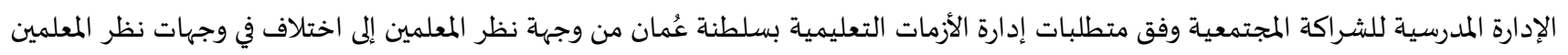

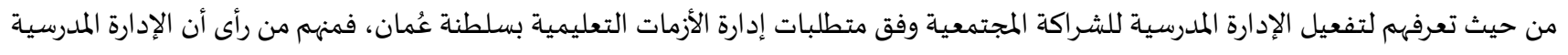

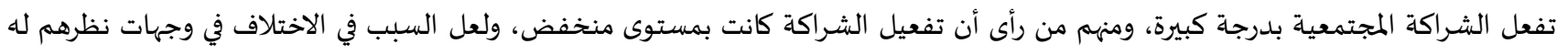
علاقة بتعدد طبيعة المدارس والظروف المحيطة بها في كل محافظة والتي لها علاقة بمستوى الشراكة المجتمعية، حيث أن أن جميع المحافظات التهات التي شملتها

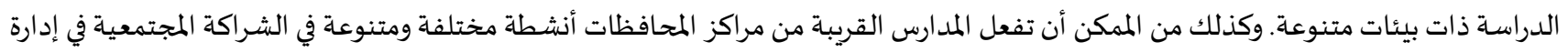

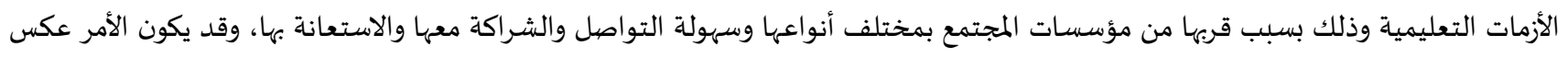
ذلك في المدارس البعيدة.

وتتفق نتيجة الدرجة الكلية للدراسة الحالية مع دراسة القحطاني (2019) التي توصلت نتائجها والتي تعبرعن ممارسات مديرات المدارس لعمليات

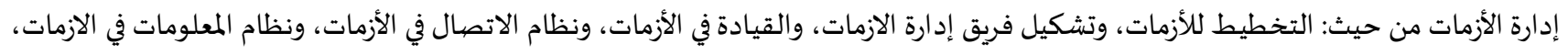
وتقويم الأزمات، الأزمات جاءت بدرجة متوسطة، وتتفق أيضا مع العريمي (2018) والتي توصلت نتائجها أن درجة توافر أبعاد الشراكة بين المات المدرسة

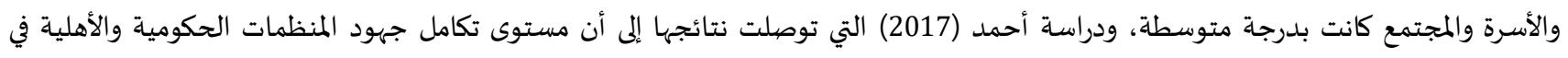

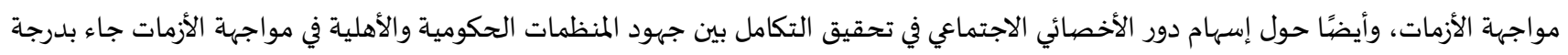

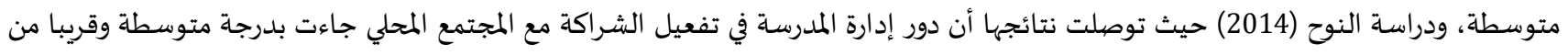

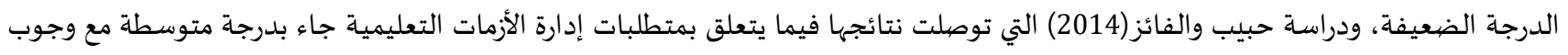

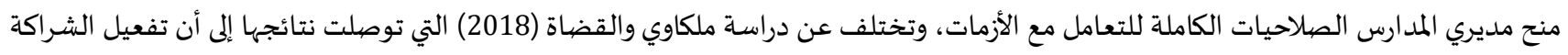

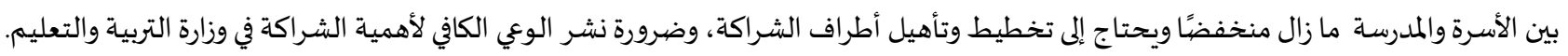
2.3. النتائج المتعلقة بالسؤال الثاني: ما المعوقات التي تواجه الإدارة المدرسية عند تفعيل الشراكة المجتمعية وفق متطلبات إدارة الأزمات

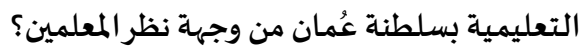

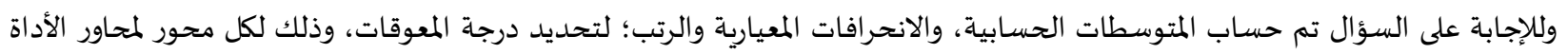
والدرجة الكلية، والجدول (4) يوضح ذلك.

جدول (4): المتوسطات الحسابية والانحر افات المعيارية لتقديرات أفراد عينة الدراسة للمعوقات التي تواجه الإدارة المدرسية عند تفعيل الشر اكة المجتمعية وفق متطلبات

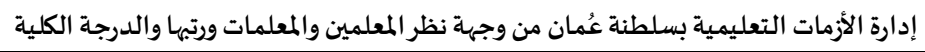

\begin{tabular}{|c|c|c|c|c|c|}
\hline درجة المو افقة & 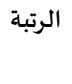 & المانحراف & الحسابي & المحاور & מ \\
\hline متوسطة & 3 & 0.25 & 2.80 & معوقات تتعلق بالمجتمع المحلي & 1 \\
\hline مرتفعة & 1 & 0.23 & 3,93 & معوقات تتعلق بالمدرسة & 2 \\
\hline 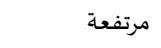 & 2 & 0.23 & 3,80 & معوقات تتعلق بالإدارة المدرسية & 3 \\
\hline متوسطة & & 0,10 & 3.22 & الدرجة الكلية & \\
\hline
\end{tabular}

يتضح من الجدول (4) أن المتوسطات الحسابية للمعوقات التي تواجه الإدارة المدرسية في تفعيل الشراكة المجتمعية وفق متطلبات إدارة الأزمات التعليمية بسلطنة عُمان من وجهة نظر المعلمين للمحاور الثلاث (معوقات تتعلق بالمجتمع المحلي، معوقات تتعلق بالمدرسة، معوقات تلتعلق المعات بالإدارة 
المدرسية) تراوحت بين (3,93-2,80)، بانحراف معياري تراوح بين (0,23-0,23)، وبلغ المتوسط الحسابي للدرجة الكلية (3,22)، وبانحراف معياري (0,10) ، بدرجة تفعيل متوسطة.

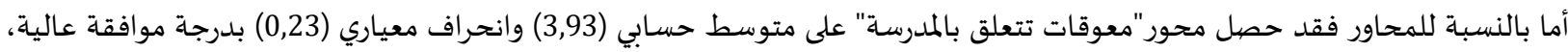

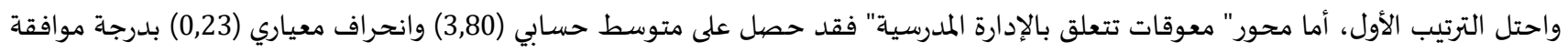
مرتفعاة، واحتل الترتيب الثاني، أما محور "معوقات تتعلق بالمجتمع المحلي" فقد حصل علد معلى متوسط حسابي (2,80) وانحراف معياري (0,25) بدرجة

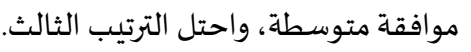

وتتفق نتيجة الدرجة الكلية للدراسة الحالية مع دراسة القحطاني (2019) والتي أشارت نتائجها إلى الافتقار من الكوادر الإدارية المتخصصة في

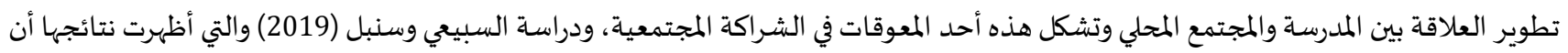

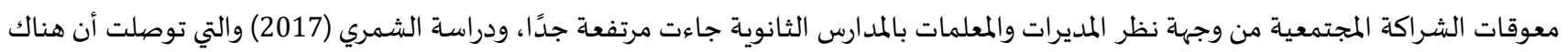

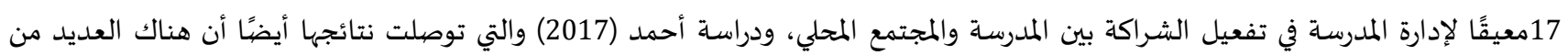

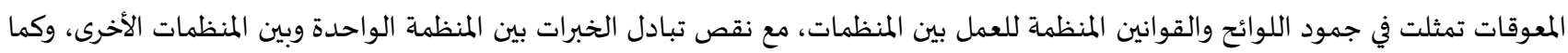

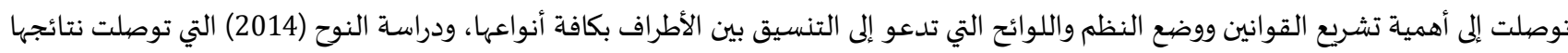

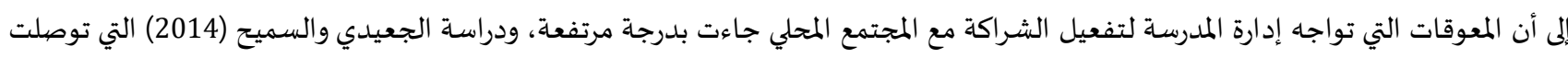

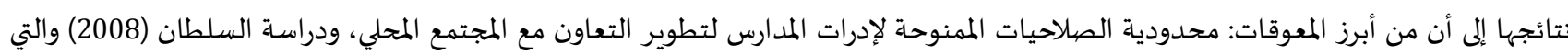
أرجعت نتائجها أسباب ضن إنف مستوز المعوفات: مجدودية التعاون بين المدرسة والمجتمع المحلي إلى وجود معوقات ذات أهمية كبيرة تحول بين إقامة علاقة تعاونية وثيقة

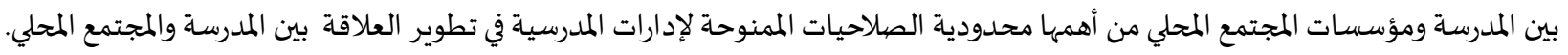
3.3. النتائج المتعلقة بالسؤال الثالث: هل توجد فروق ذات دلالة إحصائية بين استجابات عينة الدراسة حول و اقع تفعيل الشراكة المجتمعية

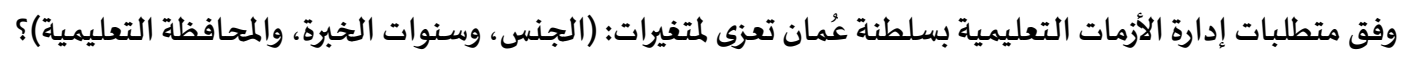

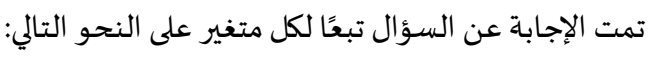

متغير الجنس:

تم استخراج المتوسطات الحسابية والانحرافات المعيارية لتقديرات أفراد عينة الدراسة على مجالات الأداة، باستخدام اختبار "ت" لعينتين

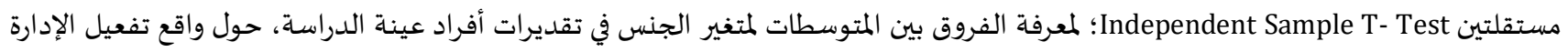
المدرسية للشراكة المجتمعية وفق متطلبات إدارة الأزمات التعليمية بسلطنة عُمان، والجدول (5) يبين ذلك.

\begin{tabular}{|c|c|c|c|c|c|c|c|}
\hline الفروق اتجاه & الإلدصائية لــــــــة & درجــــــات & "تيمة & الالنحراف & المستوسط & الجنس & المحاور \\
\hline \multirow[t]{2}{*}{ غير دالة } & 0,393 & 1464 & 0.166 & 0,20 & 3,01 & ذكر & التواصل والمعلومات \\
\hline & 0,395 & & 0.040 & 0,20 & 3,02 & أنثى & \\
\hline \multirow[t]{2}{*}{ غير دالة } & 0,303 & 1464 & 0.101 & 0,25 & 2,21 & ذكر & التخطيط والتنبؤ الوقائي \\
\hline & 0,319 & & 0.054 & 0,22 & 2,22 & أنثى & \\
\hline \multirow[t]{2}{*}{ دالة } & 0.001 & 1464 & 0,098 & 0,21 & 3,52 & ذكر & المهارات القيادية وبناء الإنسانية \\
\hline & 0,001 & & 0.046 & 0,22 & 3,57 & أنثى & \\
\hline \multirow[t]{2}{*}{ غير دالة } & 0.122 & 1464 & 0,47 & 0,10 & 3,22 & ذكر & المجموع الكلي \\
\hline & 0,120 & & & 0,10 & 3,22 & انثى & \\
\hline
\end{tabular}

يتضح من الجدول (5) عدم وجود فروق ذات دلالة إحصائية عند مستوى الدلالة (0.05 م ) بين تقديرات أفراد عينة الدراسة لواقع تفعيل

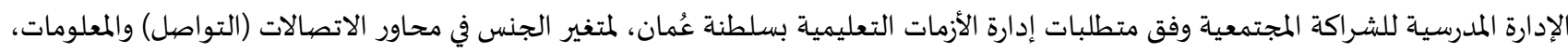

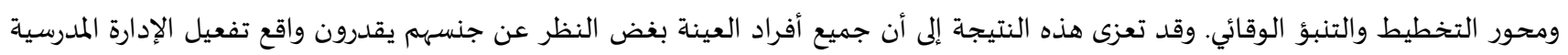

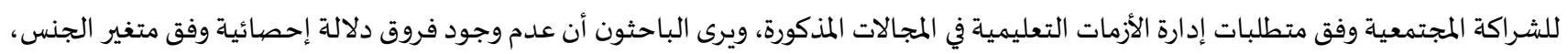

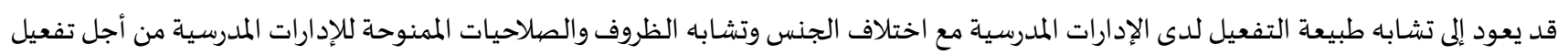

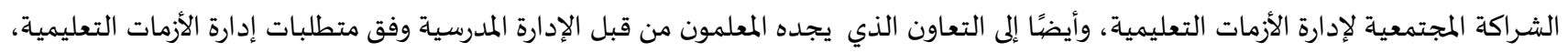

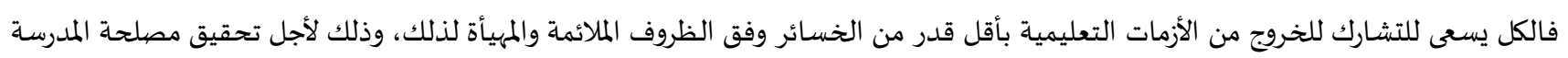

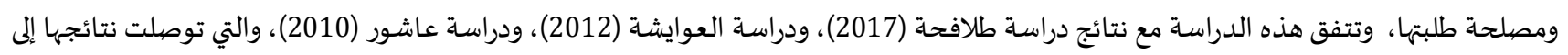


عدم وجود فروق ذات دلالة إحصائية تعزى لمتغير الجنس، وتختلف هذه الدراسة عن نتائج دراسة السعدي (2013) والتي توصلت نتائجها إلى وجود

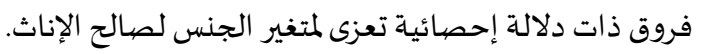
بينما توجد فروق ذات دلالة إحصائية عند مستوى الدلالة (0.05 0 (م) بين تقديرات أفراد عينة الدراسة لواقع تفعيل الإدارة المدرسية للشراكة

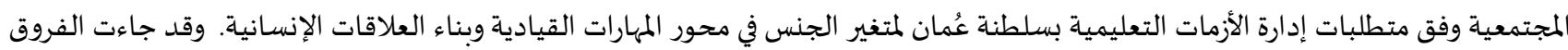

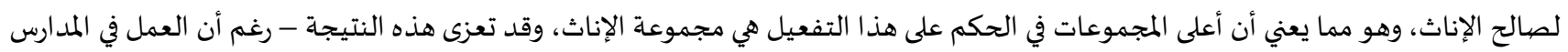

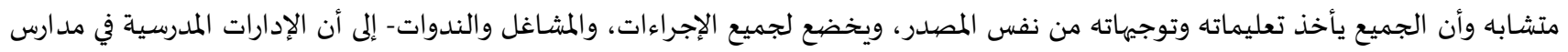

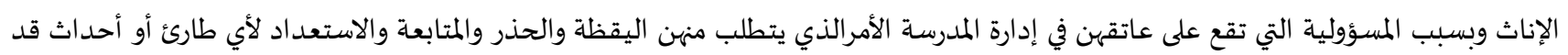

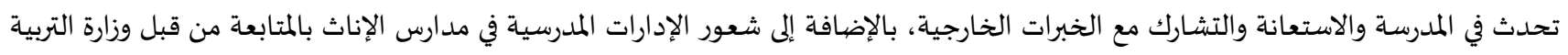

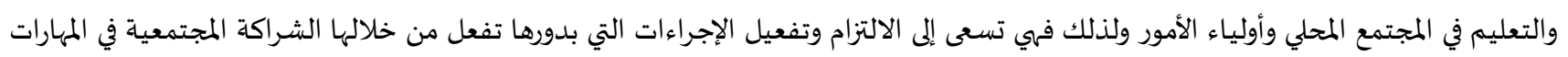

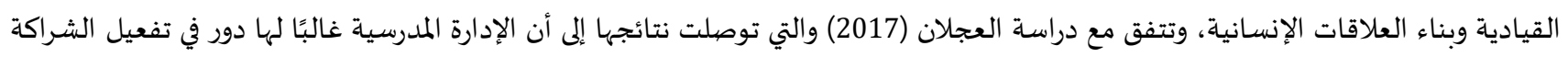

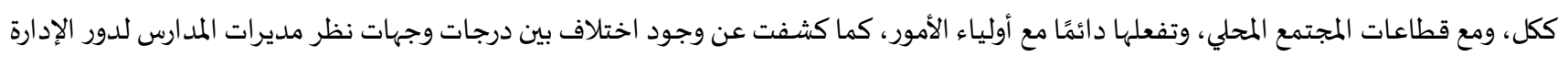

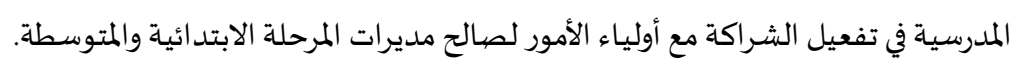

•

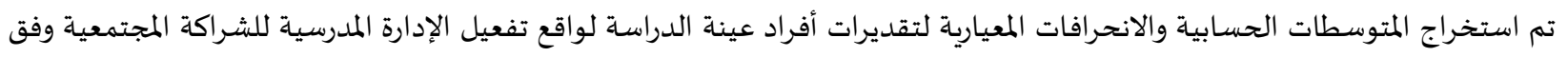

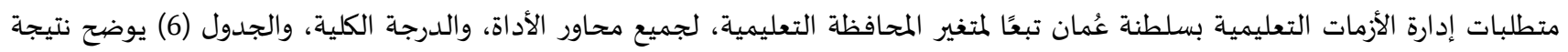

المعالجة الإحصائية.

جدول (6): تقديرات أفراد العينة على محاور الأداة والدرجة الكلية لمتغير المحافظة

\begin{tabular}{|c|c|c|c|c|}
\hline الانحراف المعياري & المتوسط الحسابي & 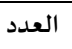 & المحافظة & المحاور \\
\hline 0.183 & 3,00 & 447 & مسقط & الاتصالات (التواصل) والمعلومات \\
\hline 0.202 & 3,04 & 347 & جنوب الباطنة & \\
\hline 0,195 & 3,03 & 210 & شمال الشرقية & \\
\hline 0,201 & 3,04 & 187 & 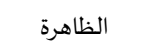 & \\
\hline 0,227 & 2,99 & 275 & ظفار & \\
\hline 0,201 & 3,02 & 1466 & المجموع & \\
\hline 0.243 & 2,21 & 477 & مسقط & التخطيط والتنبؤ الوقائي \\
\hline 0.230 & 2,21 & 347 & جنوب الباطنة & \\
\hline 0,211 & 2,23 & 210 & شمال الشرقية & \\
\hline 0,212 & 2,25 & 187 & الظاهرة & \\
\hline 0,245 & 2,20 & 275 & 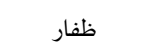 & \\
\hline 0,232 & 2,22 & 1466 & المجموع & \\
\hline 0,215 & 3,54 & 477 & مسقط & المهارات القيادية وبناء العلاقات \\
\hline 0.226 & 3,56 & 347 & جنوب الباطنة & الإنسانية \\
\hline 0,205 & 3,52 & 210 & شمال الشرقية & \\
\hline 0,203 & 3,56 & 187 & 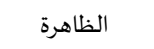 & \\
\hline 0,207 & 3,53 & 275 & 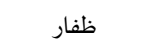 & \\
\hline 0,214 & 3,54 & 1466 & المجموع & \\
\hline 0.098 & 3,22 & 477 & مسقط & الدرجة الكلية \\
\hline 0,104 & 3,22 & 347 & جنوب الباطنة & \\
\hline 0,101 & 3,20 & 210 & شمال الشرقية & \\
\hline 0,099 & 3,24 & 187 & 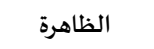 & \\
\hline 0,111 & 3,21 & 275 & 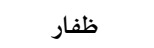 & \\
\hline 0.103 & 3,22 & 1466 & المجموع & \\
\hline
\end{tabular}

يتضح من الجدول (6) وجود فروق ظاهرية بين متوسطات عينة الدراسة لمتغير المحافظة، ولمعرفة ما إذا كان هناك فروق ذات دلالة إحصائية تعزى لمتغير المحافظة نستخدم تحليل التباين الأحادي؛ للمقارنة بين المحافظات في كل محاور الدراسة والدورجة الدورئ الكلية والجدول (7) يوضح ذلك. 


\begin{tabular}{lcccccc}
\multicolumn{7}{c}{} \\
\hline
\end{tabular}

يتضح من خلال الجدول (7) وجود فروق ذات دلالة إحصائية عند مستوى الدلالة (0.05 به ) بين تقديرات أفراد عينة الدراسة لواقع تفعيل

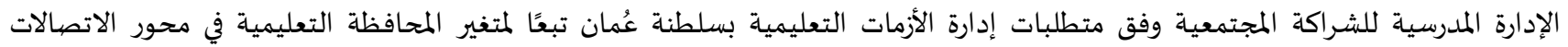

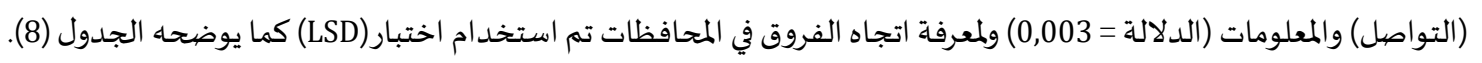
جدول (8): نتائج اختبار (LSD) للمقارنة البعدية في متغير المحافظة التعليمية

\begin{tabular}{|c|c|c|c|c|c|}
\hline \multirow[t]{2}{*}{ الدلالة الإحصائية } & \multirow{2}{*}{ المعياري } & \multirow{2}{*}{ المتروق بين } & \multicolumn{2}{|c|}{ المحافظة } & \multirow[t]{2}{*}{ المجال } \\
\hline & & & & & \\
\hline 0,004 & 0,014 & $* 0.041$ & جنوب الباطنة & مسقط & لتواصل والمعلومات \\
\hline 0,023 & 0,018 & $* 0.039$ & الظاهرة & & \\
\hline 0.033 & 0,017 & $* 0,035$ & شمال الشرقية & & \\
\hline 0,669 & 0,154 & 0.006 & ظفار & & \\
\hline
\end{tabular}

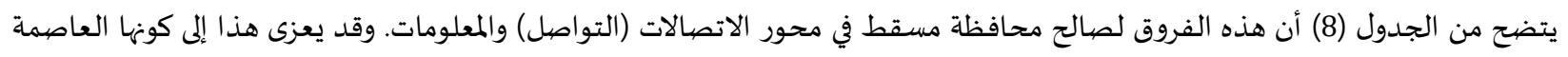

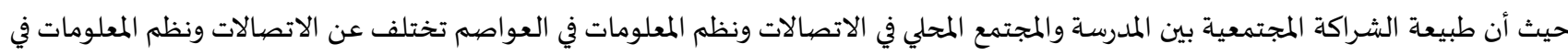

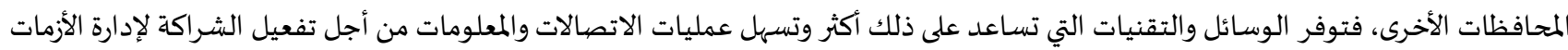

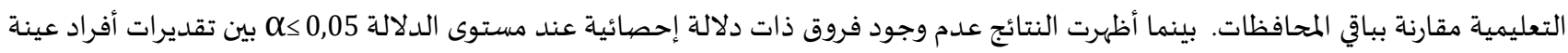

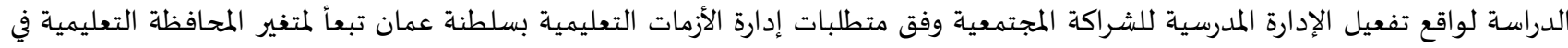

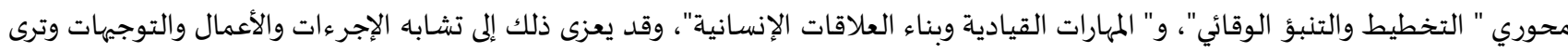
عينة الدراسة الإدارات المدرسية تعمل بها حتى وإن اختلفت طبيعة المحافظات ويبقى الاختلاف فقط في مستوى درجة التفعيل واختلافه بين إدارة مدرسية وأخرى.

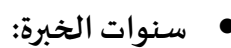

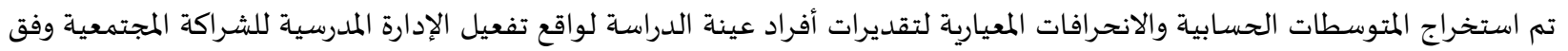

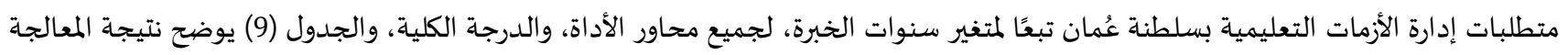
الإحصائية.

جدول (9): تقديرات أفراد العينة على محاور الأداة والدرجة الكلية لمتغيرسنوات الخبرة

\begin{tabular}{|c|c|c|c|c|}
\hline الانحراف المعيارية & المتوسط الحسابي & العدد العد & سنوات الخبرة & المحاور \\
\hline 0.204 & 3,024 & 436 & 5 سنوات فأقل & الاتصالات (التواصل) \\
\hline $\begin{array}{l}0.200 \\
0.202\end{array}$ & 3,017 & 528 & أكثر من 5 إلى 10 سنوات & والمعلومات \\
\hline 0,202 & 3,028 & & أكثر من 10 سنوات & \\
\hline 0,201 & 3,021 & 1466 & المجموع & \\
\hline 0.244 & 2,226 & 436 & 5 سنوات فأقل & الخطيط والتنبؤ الوقائي \\
\hline 0.222 & 2,229 & 528 & أكثر من 5 إلى 10 سنوات & \\
\hline 0,233 & 2,213 & 502 & أكثر من من 10 سنوات ستوات & \\
\hline
\end{tabular}




\begin{tabular}{|c|c|c|c|c|}
\hline 0,232 & 2,221 & 1466 & المجموع & \\
\hline 0,197 & 3,548 & 436 & 5 سنوات فأقل 5 & المهارات القيادية وبناء \\
\hline 0.211 & 3,546 & 528 & أكثر م. 5 عله 10 سنهات & العلاقات الانسانية \\
\hline \multirow[t]{2}{*}{0,223} & 3,542 & 502 & أكثر من 5 على 10 سنوات & العلاقات الإنسانية \\
\hline & & & أكثر من 10 سنوات & \\
\hline 0,214 & 3,544 & 1466 & المجموع & \\
\hline 0.102 & 3,225 & 436 & 5 سنوات فأقل 5 & الدرجة الكلية \\
\hline 0,106 & 3,223 & 528 & & \\
\hline \multirow[t]{2}{*}{0,102} & 3,219 & 502 & اكتر من 5 إلى 10 سنوات & \\
\hline & & & أكثر من 10 سنوات & \\
\hline 0,103 & 3,22 & 1466 & المجموع & \\
\hline
\end{tabular}

يتضح من الجدول (9) وجود فروق ظاهرية بين متوسطات عينة الدراسة لمتغير سنوات الخبرة، ولمعرفة ما إذا كان هناك فروق ذات دلالة

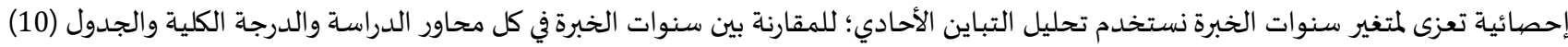
يوضح ذلك

جدول (10): المتوسطات الحسابية والانحر افات المعيارية لتحليل التباين الأحادي لمتغيرسنوات الخبرة لجميع محاور أداة الدراسة

\begin{tabular}{|c|c|c|c|c|c|c|}
\hline مستوى & قيمة & متوسط & درجة الحرية & مجموع & مصدر التباين & المحاور \\
\hline 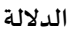 & ف & المربعات & & المربعات & & \\
\hline \multirow[t]{3}{*}{0,874} & 0,135 & 0.006 & 2 & 0,011 & بين المجموعات & التواصل والمعلومات \\
\hline & & 0.041 & 1463 & 59,676 & داخل المجموعات & \\
\hline & & & 1465 & 59,687 & المجموع الكلي & \\
\hline \multirow[t]{3}{*}{0,494} & 0,706 & 0.038 & 2 & 0,077 & بين المجموعات & التخطيط والتنبؤ الوقائي \\
\hline & & 0.054 & 1463 & 79,420 & داخل المجموعات & \\
\hline & & & 1465 & 79,497 & المجموع الكلي & \\
\hline \multirow[t]{3}{*}{0.910} & 0.094 & 0,004 & 2 & 0,009 & بين المجموعات & المهارات القيادية وبناء \\
\hline & & 0.046 & 1463 & 67,112 & داخل المجموعات & العلاقات الإنسانية \\
\hline & & & 1465 & 67,121 & المجموع الكلي & \\
\hline \multirow[t]{3}{*}{0.638} & 0,450 & 0,005 & 2 & 0,010 & يين المجموعات & المجموع الكلي \\
\hline & & 0,011 & 1463 & 15,619 & داخل المجمموعات & \\
\hline & & & 1465 & 15 & المجموع الكلي & \\
\hline
\end{tabular}

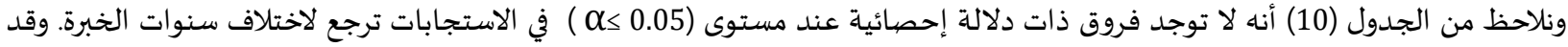

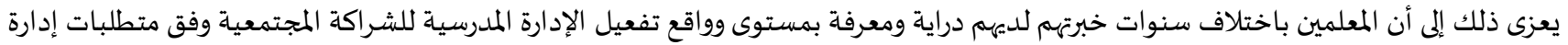

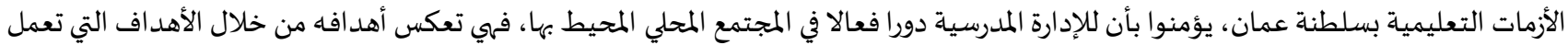

على تحقيقها.

4.3. النتائج المتعلقة بالسؤال الر ابع: هل توجد فروق ذات دلالة إحصائية بين استجابات عينة الدراسة حول المعوقات التي تحول دون تفعيل

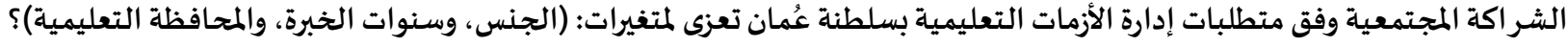

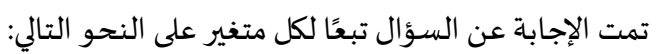

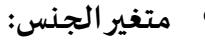

تم استخراج المتوسطات الحسابية والانحرافات المعيارية لتقديرات أفراد عينة الدراسة على محاور الأداة، باستخدام اختبار "ت" لعينتين مستقلتين Indepndent Sample T- Test المعرفة الفروق بين المتوسطات لمتغير الجنس في تقديرات أفراد عينة الدراسة، حول واقع معوقات تفعيل الإدارة المدرسية للشراكة المجتمعية وفق متطلبات إدارة الأزمات التعليمية بسلطنة عُمان، والجدول (11) يبين ذلك.

\begin{tabular}{|c|c|c|c|c|c|c|c|}
\hline اتجاه الفروق & $\begin{array}{c}\text { الإحصائية } \\
\text { الدلائة }\end{array}$ & درجات الحرية & "تيمة & المعياري & المستوسطي & الجنس & المحاور \\
\hline \multirow[t]{2}{*}{ غير دالة } & 0,930 & 1464 & 0.088 & 0,237 & 2,807 & ذكر & معوقات تتعلق بالمجتمع \\
\hline & 0,927 & & 0.091 & 0,261 & 2,808 & 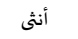 & المحلي \\
\hline \multirow[t]{2}{*}{ غير دالة } & 0,580 & 1464 & 0.554 & 0,215 & 3,939 & ذكر & معوقات تتعلق بالمدرسة \\
\hline & 0,570 & & 0.569 & 0,231 & 9,932 & أنثى & \\
\hline \multirow[t]{2}{*}{ غير دالة } & 0.863 & 1464 & 0,173 & 0,248 & 3,802 & ذكر & معوقات تتعلق بالإدارة \\
\hline & 0,867 & & 0.167 & 0,225 & 3,801 & 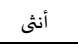 & المدرسية \\
\hline \multirow[t]{2}{*}{ غيردالة } & 0.122 & 1464 & 1,102 & 0,102 & 3,216 & ذكر & المجموع الكلي \\
\hline & 0,120 & & 1,558 & 0,104 & 3,224 & 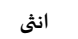 & \\
\hline
\end{tabular}




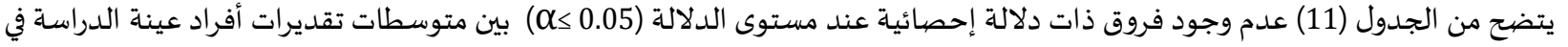

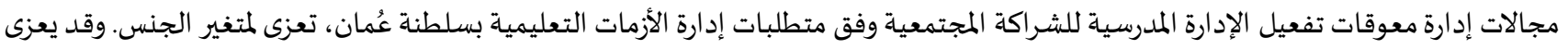

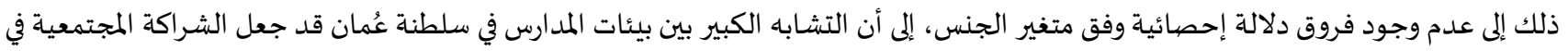

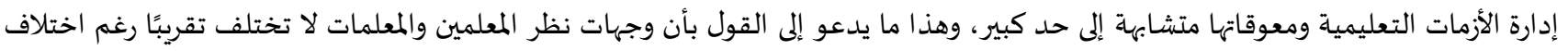

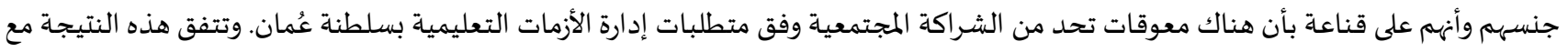

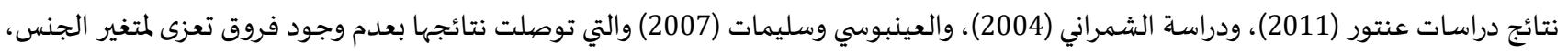
بينما تختلف هذه الدراسة مع دراستي بركات (2007)، والحلو (2009) والتي توصلت نتائجها في وجود فروق دالة إستاني إحصائيًا وفق متغير الجنس.

•

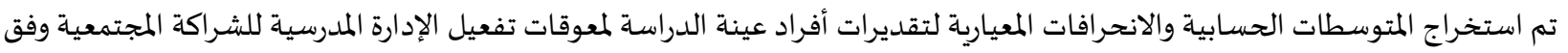

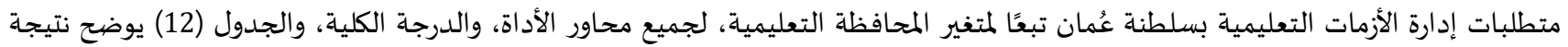

المعالجة الإحصائية.

\begin{tabular}{|c|c|c|c|c|}
\hline الانحراف المعياري & المتوسط الحسابي & العدد & المحافظة & المجالات \\
\hline 0.247 & 2,83 & 447 & مسقط & معوقات تتعلق بالمجتمع \\
\hline 0.252 & 2,78 & 347 & & المحلد \\
\hline 0,231 & 2,77 & 210 & جنوب الباطنة & \\
\hline 0,273 & 2,89 & 187 & شمال الشرقية & \\
\hline \multirow[t]{2}{*}{0,251} & 2,78 & 275 & الظاهرة & \\
\hline & & & 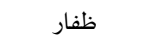 & \\
\hline 0,253 & 2,81 & 1466 & المجموع & \\
\hline 0.243 & 3,93 & 477 & مسقط & معوقات تتعلق بالمدرسة \\
\hline 0.204 & 3,92 & 347 & & \\
\hline 0,199 & 3,94 & 210 & جنوب الباطنة & \\
\hline 0,216 & 3,92 & 187 & شمال الشرقية & \\
\hline \multirow[t]{2}{*}{0,247} & 3,96 & 275 & الظاهرة & \\
\hline & & & 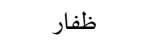 & \\
\hline 0,226 & 3,93 & 1466 & المجموع & \\
\hline 0,229 & 3,80 & 477 & مسقط & معوقات تتعلق بالإدارة \\
\hline 0.232 & 3,81 & 347 & & a \\
\hline 0,260 & 3,57 & 210 & جنوب الباطنة & المدرسية \\
\hline 0,205 & 3,82 & 187 & شمال الشرقية & \\
\hline \multirow[t]{2}{*}{0,230} & 3,81 & 275 & الظاهرة & \\
\hline & & & 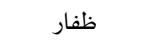 & \\
\hline 0,232 & 3,80 & 1466 & المجموع & \\
\hline 0.098 & 3,22 & 477 & مسقط & الدرجة الكلية \\
\hline 0,104 & 3,22 & 347 & 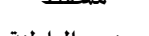 & الدمربه أميل \\
\hline 0,101 & 3,20 & 210 & جنوب الباطنة & \\
\hline 0,099 & 3,24 & 187 & شمال الشرقية & \\
\hline \multirow[t]{2}{*}{0,111} & 3,21 & 275 & الظاهرة & \\
\hline & & & ظفار & \\
\hline 0.103 & 3,22 & 1466 & المجموع & \\
\hline
\end{tabular}

يتضح من الجدول (12) وجود فروق ظاهرية بين متوسطات عينة الدراسـة لمتغير المحافظة ولمعرفة ما إذا كان هناك فروق ذات دلالة إحصائية

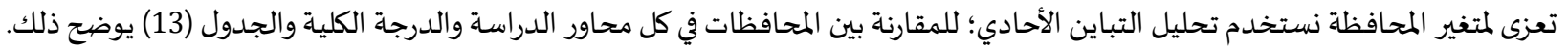

\begin{tabular}{|c|c|c|c|c|c|c|}
\hline \multirow[t]{2}{*}{ مستوى الدلالة } & قيمة & متوسط & درجة & مجموع & مصدر التباين & المحاور \\
\hline & ف & المربعات & الحرية & المربعات & & \\
\hline \multirow[t]{3}{*}{0,000} & 9,113 & 0.572 & 4 & 2,290 & بين المجموعات & معوقـات تتعلقق بـالمجتمع \\
\hline & & 0.063 & 1461 & 91,765 & داخل المجموعات & المحلي \\
\hline & & & 1465 & 94,054 & المجموع الكلي & \\
\hline \multirow[t]{3}{*}{0,171} & 1,602 & 0.082 & 4 & 0,327 & بين المجموعات & معوقات تتعلق بالمدرسة \\
\hline & & 0.051 & 1461 & 74,597 & داخل المجموعات & \\
\hline & & & 1465 & 74,924 & المجموع الكلي & \\
\hline
\end{tabular}




\begin{tabular}{|c|c|c|c|c|c|c|}
\hline \multirow[t]{3}{*}{0.020} & 2.933 & 0,158 & 4 & 0,632 & بين المجموعات & \multirow{3}{*}{ معوقـات تتعلـق بـالإدارة } \\
\hline & & \multirow[t]{2}{*}{0.054} & 1461 & 78,749 & داخل المجموعات & \\
\hline & & & 1465 & 79,381 & المجموع الكلي & \\
\hline \multirow[t]{3}{*}{0.001} & 4,471 & 0,47 & 4 & 0,189 & بين المجموعات & المجموع الكلي \\
\hline & & \multirow[t]{2}{*}{0,011} & 1461 & 15,440 & داخل المجموعات & \\
\hline & & & 1465 & 15,629 & المجموع الكلي & \\
\hline
\end{tabular}

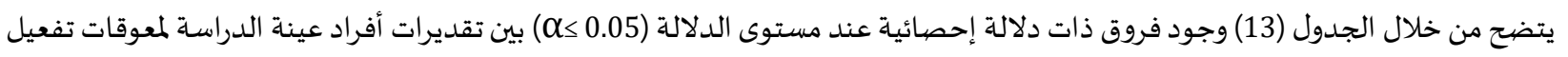

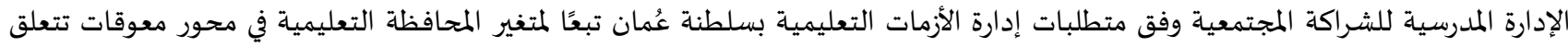

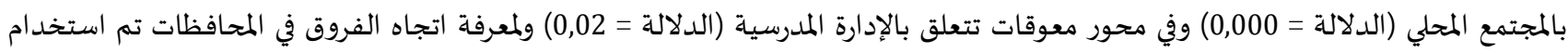

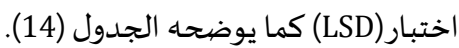

جدول (14): نتائج اختبار (LSD) للمقارنة البعدية في متغير المحافظة التعليمية

\begin{tabular}{|c|c|c|c|c|}
\hline الدلالة الإحصيائية & الخطأ المعياري & الفروق بين المتوسطات & المحافظة & المجال \\
\hline 0,003 & 0,017 & ${ }^{*} 0.055$ & مسقط & الظاهرة \\
\hline 0,002 & 0,020 & ${ }^{*} 0.108$ & حنهب اللاطنة & \\
\hline $\begin{array}{l}0.012 \\
0.008\end{array}$ & 0,021 & ${ }^{*} 0,121$ & جنوب الباطنه & رعوتات لتحلق بالمجسمع \\
\hline 0,008 & 0,192 & $* 0.106$ & شمال الشرقية & المحلي) \\
\hline 0.006 & 0,019 & $* 0.053$ & جنوب الباطنة & الشرقية شمال \\
\hline 0,05 & 0,020 & $* 0.057$ & الظاهرة الظ & (معوقات تتعلق بالإدارة \\
\hline \multirow{2}{*}{0,01} & $\begin{array}{l}0,023 \\
0,021\end{array}$ & *0,071 & شمال الشرقية & المدرسية) \\
\hline & & $* 0.053$ & شفار اسر & \\
\hline
\end{tabular}

يتضح من الجدول (14) أن هذه الفروق لصالح محافظة الظاهرة في محور معوقات تتعلق بالمجتمع المحلي، ولصالح محافظة شمال الشرقية في

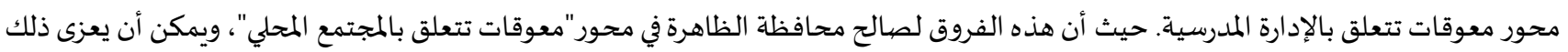

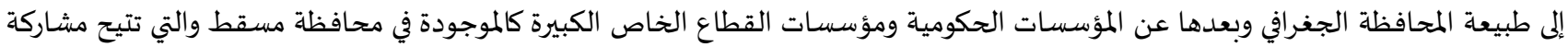

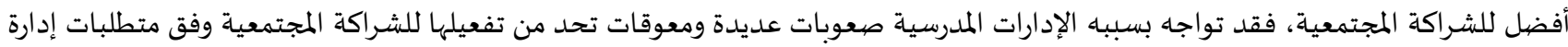

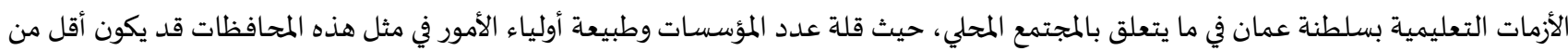

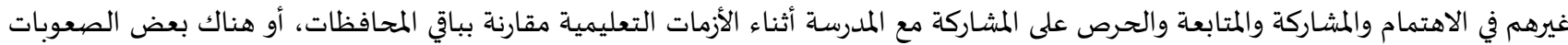

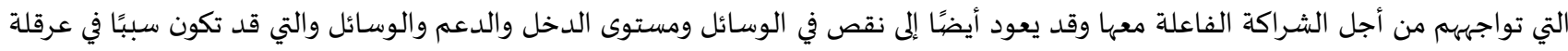

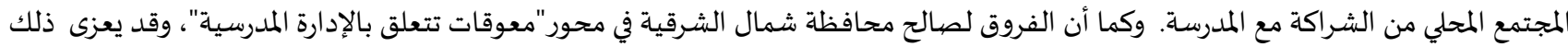

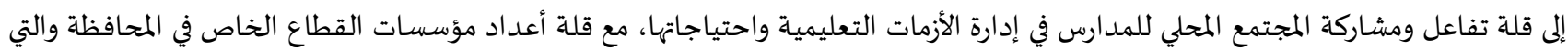

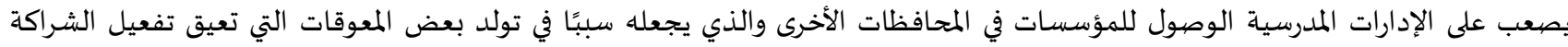

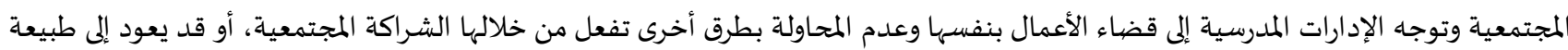

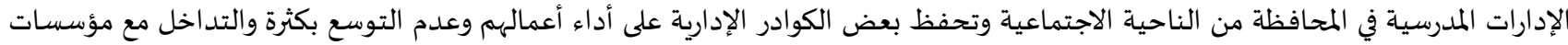

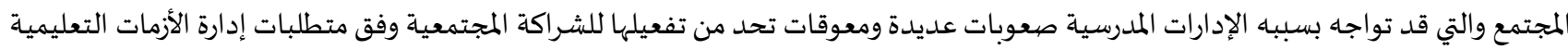

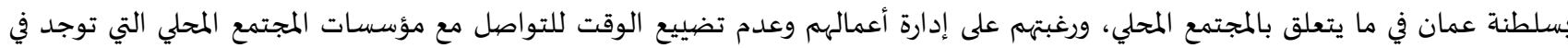

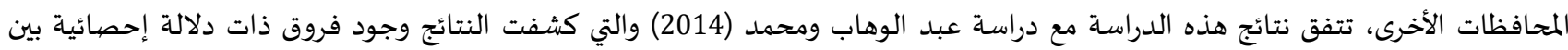

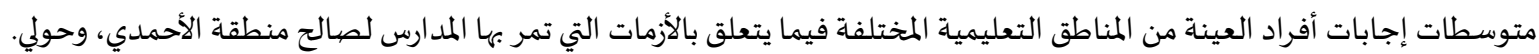

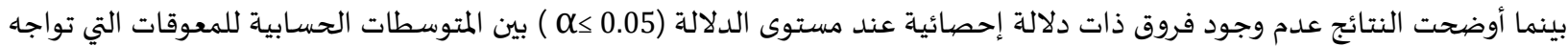

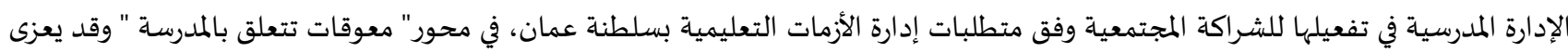
ذلك على اتفاق وجهات عينة الدراسة رغم اختلاف محافظاتهم التعليمية على المعوقات المتعلقة بالمدرسة وتشابها، وقد يكون ذلك بسبب تشابه التوجيهات والامكانيات الممنوحة للمدارس. سنوات الخبرة:

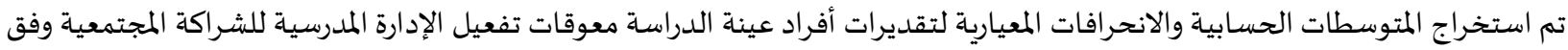

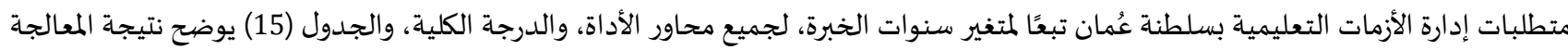

الإحصائية. 
جدول (15): تقديرات أفراد العينة على محاور الأداة والدرجة الكلية لمتغير سنوات الخبرة

\begin{tabular}{|c|c|c|c|c|c|c|}
\hline الانحراف المعياري & & المتوسط الحسابي & العدد العدد & \multicolumn{2}{|c|}{ سنوات الخبرة } & المحاور \\
\hline 0.204 & & 2,797 & 436 & \multicolumn{2}{|c|}{5 سنوات فأقل } & معوقات تتعلق بالمجتمع \\
\hline 0.200 & & 2,815 & 528 & \multicolumn{2}{|c|}{ 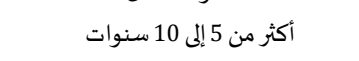 } & المحلى \\
\hline 0,202 & & 2,807 & 502 & \multicolumn{2}{|c|}{ أكثر من 10 سنوات } & \\
\hline 0,201 & & 2,808 & 1466 & \multicolumn{2}{|c|}{ المجموع } & \\
\hline 0.244 & & 3,949 & 436 & \multicolumn{2}{|c|}{5 سنوات فأقل } & معوقات تتعلق بالمدرسة \\
\hline $\begin{array}{l}0.222 \\
0.233\end{array}$ & & $\begin{array}{l}3,931 \\
3,930\end{array}$ & $\begin{array}{l}528 \\
502\end{array}$ & \multirow{2}{*}{\multicolumn{2}{|c|}{ أكثر من 5 إلى 10 سنوات 10 سنوات }} & \\
\hline & & 3,930 & & & & \\
\hline 0,232 & & 3,934 & 1466 & \multicolumn{2}{|c|}{ المجموع } & \\
\hline 0,197 & & 3,806 & $\begin{array}{l}436 \\
538\end{array}$ & \multirow{3}{*}{\multicolumn{2}{|c|}{ 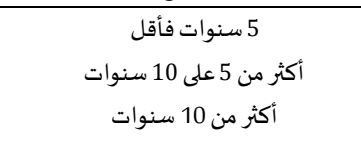 }} & معوقات تتعلق بالإدارة \\
\hline 0.211 & & $\begin{array}{l}3,223 \\
3,219\end{array}$ & $\begin{array}{l}528 \\
502\end{array}$ & & & المدرسية \\
\hline & & & & & & \\
\hline 0,214 & & 3,802 & 1466 & \multicolumn{2}{|c|}{ المجموع } & \\
\hline 0.102 & & 3,225 & & \multirow{3}{*}{\multicolumn{2}{|c|}{ 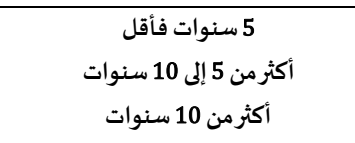 }} & الدرجة الكلية \\
\hline $\begin{array}{l}0,106 \\
0,102\end{array}$ & & $\begin{array}{l}3,223 \\
3,219\end{array}$ & $\begin{array}{l}528 \\
502\end{array}$ & & & \\
\hline & & & & & & \\
\hline 0,103 & & 3,222 & 1466 & \multicolumn{2}{|c|}{ المجموع } & \\
\hline \multicolumn{7}{|c|}{ جدول (16): المتوسطات الحسابية والانحر افات المعيارية لتحليل التباين الأحادي لمتغيرسنوات الخبرة لجميع محاورأداة الدراسة } \\
\hline مستوى & قيمة & متوسط & درجة الحرية & مجموع & مصدر & المحاور \\
\hline الدلالة & ف & المربعات & & المربعات & التباين & \\
\hline \multirow[t]{3}{*}{0,619} & 0,480 & 0.031 & 2 & 0,062 & بين المجموعات & معوقات تتعلق بالمجتمع \\
\hline & & 0.064 & 1463 & 93,993 & داخل المجموعات & المحلي \\
\hline & & & 1465 & 94,054 & المجموع الكلي & \\
\hline \multirow[t]{3}{*}{0,478} & 0,739 & 0.038 & 2 & 0,076 & بين المجموعات & معوقات تتعلق بالمدرسة \\
\hline & & 0.051 & 1463 & 74,849 & داخل المجموعات & \\
\hline & & & 1465 & 74,924 & المجموع الكلي & \\
\hline \multirow[t]{3}{*}{0.873} & 0.135 & 0,007 & 2 & 0,015 & بين المجموعات & معوقات تتعلق بالإدارة \\
\hline & & 0.054 & 1463 & 79,367 & داخل المجموعات & المدرسية \\
\hline & & & 1465 & 79,381 & المجموع الكلي & \\
\hline \multirow[t]{3}{*}{0.638} & 0,450 & 0,005 & 2 & 0,010 & يين المجموعات & المجموع الكلي \\
\hline & & 0,011 & 1463 & 15,619 & داخل المجمموعات & \\
\hline & & & 1465 & 15,629 & المجموع الكلي & \\
\hline
\end{tabular}

يتضح من الجدول (16) عدم وجود فروق ذات دلالة إحصائية على مستوى الدلالة (0.05 0 (م) بين متوسطات وجهات أفراد العينة في مجال

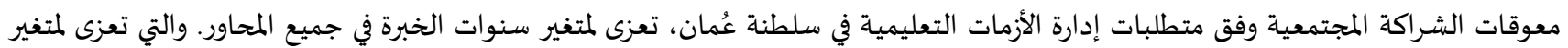
سنوات الخبرة، وتعزو الباحثة عدم وجود فروق ذات دلالة إحصائية وفق متغير سنوات الخبرة؛ قد يعود إلى القناعة والاتفاق لدى أفراد العينة على إنى

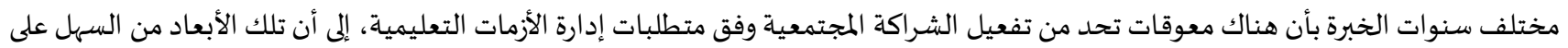

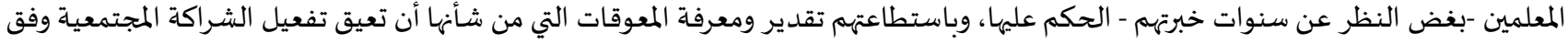
متطلبات إدارة الأزمات التعليمية، وهذا يعني أيضًا أن عينة الدراسة مهما اختلفت سنوات خبرتهاتهم يؤكدون على واقع المعوقات المات التي تعيق من تفعيل

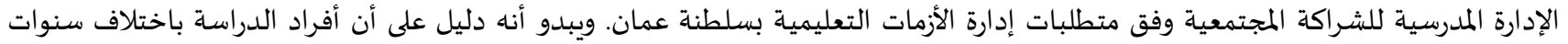

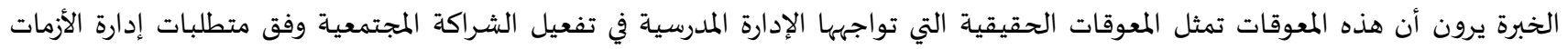
التعليمية باختلاف سنوات خبرتهم، وتتفق مع دراسة الخميس والصالحي (2019)، ودراسـة الجهني (2010).

5.3 في ضوء الإطار النظري ونتائج الدراسـة يقترح الآتي:

• أولاً: محور الاتّصالات (التواصل) والمعلومات: منح أولياء الأمور، والمجتمع المحلي صلاحيات أكبر للمشاركة في تنفيذ وتقييم برامج وأنشطة

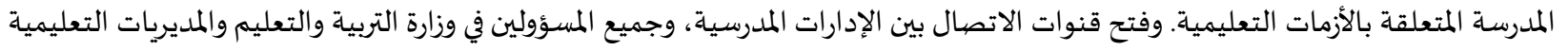
لتقييم خطط إدارة الأزمات التعليمية. إعطاء صلاحيات للإدارات المدرسية في استقطاب جهات المجتمع المختلفة دون الرجوع للمديريات؛ مما 
يسّهل تفعيل الشراكة المجتمعية وفق متطلبات إدارة الأزمات التعليمية. الاستفادة من إدارات المدارس ذات التجارب الناجحة، وتعميمها على إلى

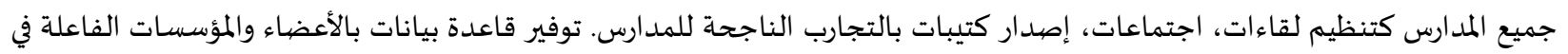
المجتمع المحلي والاستفادة من التكنولوجيا الحديثة بتوظيفها في إنشاء هذه القاعدة للاستفادة منها في الشراكة المجتمعية لإدارة الأزمات

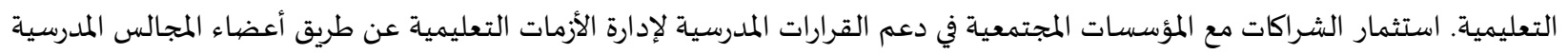

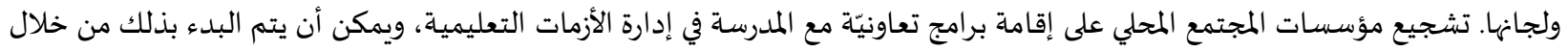

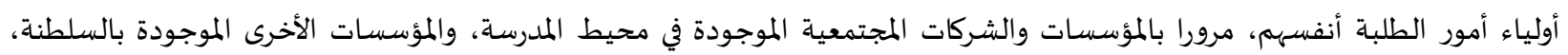

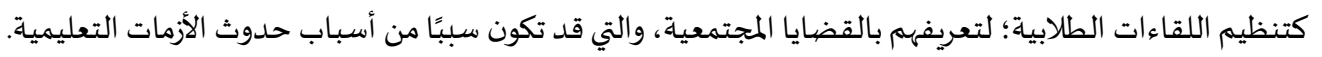
ثانيًا: محور التخطيط والتنبؤ الوقائي: التخطيط السليم لبرامج الشراكة المجتمعية وفق متطلبات إدارة الأزمات التعليمياة، والوضوح في تحديد

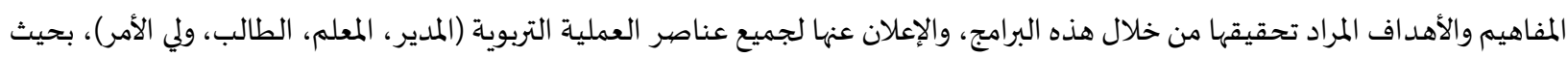

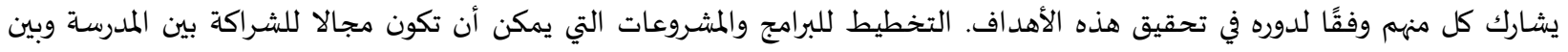

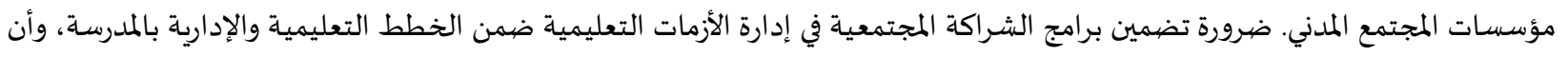

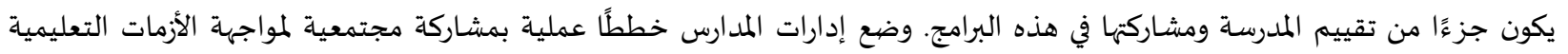

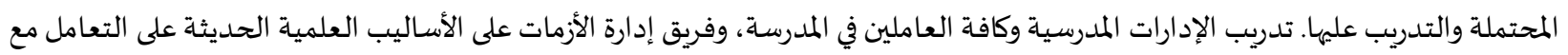

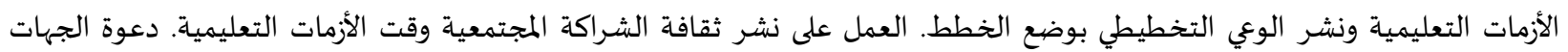

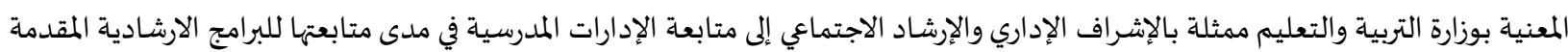

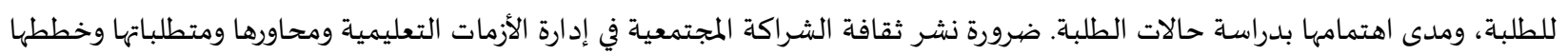
بين العاملين في القطاع التعليمي من معلمين وإداريين وتربويين، بحيث يكون لهذه الشراكة وجود في الخطط التعلئيمية.

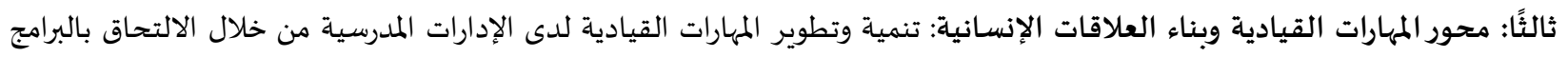

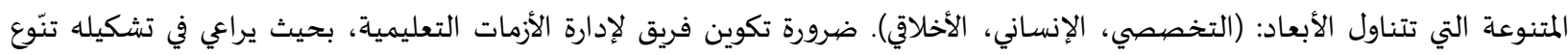

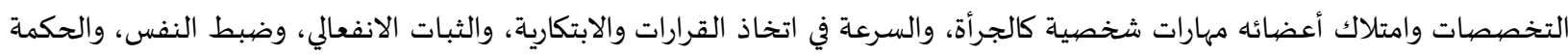

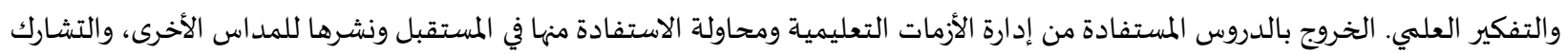

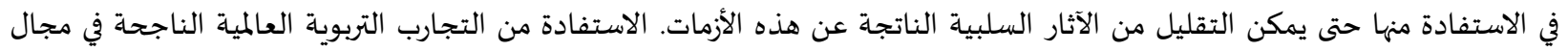
الشراكة في إدارة الأزمات التعليمياة.

6.3. توصيات ومقترحات عامة:

توجياء طلبة الدراسات العليا لإجراء مزيلٍ من الدراسات والبحوث حول الشراكة المجتمعية وفق متطلبات إدارة الأزمات التعليمية. وتشجيع إدارة

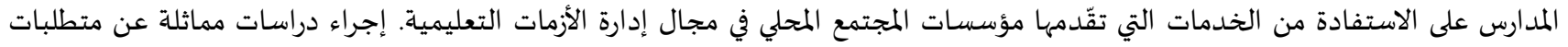

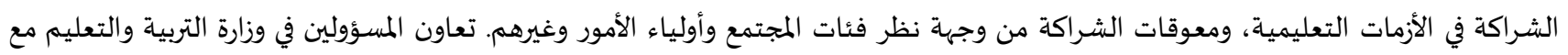

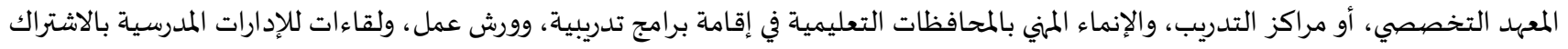

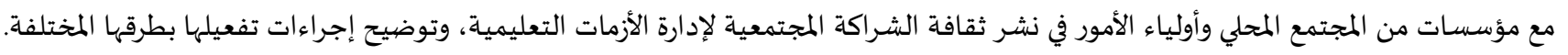

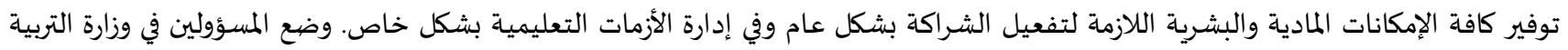

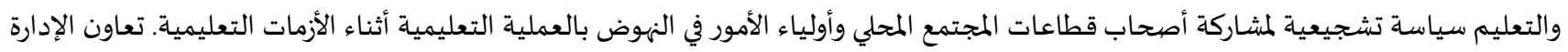

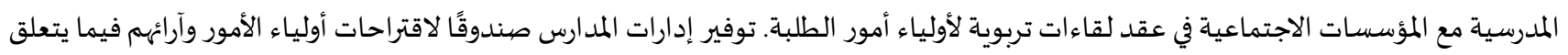

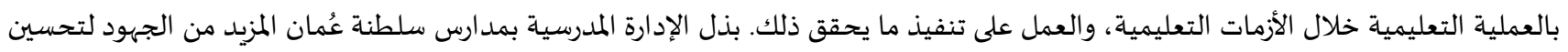

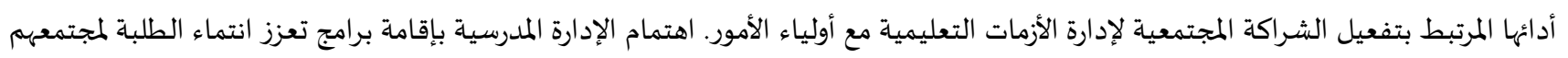

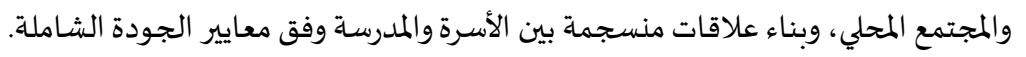

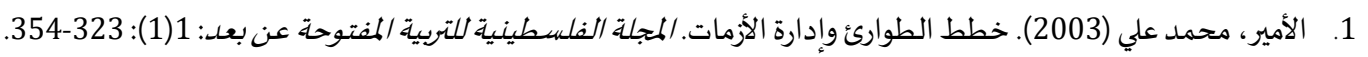
2. أحمد، عصام بدري (2017). تكامل جهود المنظمات الحكومية والأهلية في مواجهة الكوارث والأزهات المجتمعية. [أطروحة دكتوراة، جامعة أسيوط] 
3. بركات، زياد (2007). مصادر الأزمات كما يدركها طلبة جامعة القدس المفتوحة. المجلة الفلسطيينية للتعليم المفتوح والتعليم الإلكتروني: 1(1): 323-

4. البيماني، وداد (2013). دور مديرات المدارس في إدارة الأزمات والكوارث. مجلة دراسات الخليج والجنيرة العببية: 11(2): 120-128.

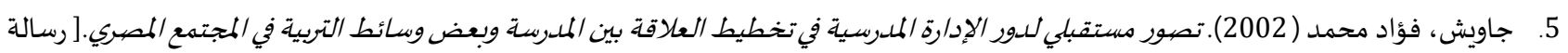

دكتوراة، جامعة القاهرة] 6. الجعيدي، والسميح (2014). دور الإدارة المدرسية في تفعيل الشراكة المجتمعية بين المدارس الثانوية للبنات والمجتمع المحلي. رسالة الخليج العربي: 189 :(35) 132

7. الجهني، عبدالله (2010). أساليب اتخاذ القرار في إدارة الأزمات المدرسية من وجهة نظر مديري المدارس بمحافظة ينبع. [رسالة ماجستير، جامعة الملك عبدالعزيز].

8. الحبسي، رحمة (2011). واقع المشاركة المجتمعية في صنع القرار التوبوي في النظام التعليمي العام بسلطنة عمان. [رسالة ماجستير، جامعة السلطان قابوس].

9. الحبيب، عبد الرحمن، والفايز، فايز (2014). إدارة الأزمات في مدارس التعليم العام بإدارة التربية والتعليم في مدينة الرياض. مجلة التوبية: (161): .581-540

10. حمدونة، حسام (2006). ممارسة مدير المدرسة الثانوية لمهارة إدارة الأزمات في محافظة غزة. مجلة العلوم النفسية والتويوية: 3(2): 112-118.

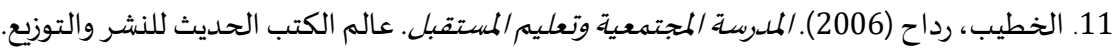

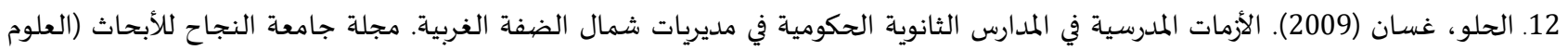
الإنسانية): 24: 223-262. 13. الخميس، ابتسام، والصالحي، خالد (2019). واقع تطبيق قائدات المدارس الثانوية لاتخاذ القرار في إدارة الأزمات المدرسية بمنطقة القصيم. المجلة الدولية للتعليم بالإنتونت: المجلد الأول: 35-64. 14. الزاملي، علي، والغنبوصي، سالم، وسليمان، سعاد (2007). الأزمات المدرسية وأساليب التعامل معها في مدارس سلطنة عمانئ المان. محجلة العلوم التوبوية

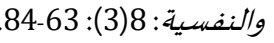
15. السبيعي، نورة، وسنبل، فائقة (2019). متطلبات الشراكة المجتمعية ومعوقاتها من وجهة نظر المديرات والمعلمات بالمدارس الثانوية بمحافظة الخرمة

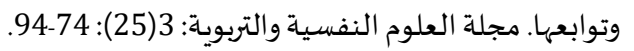

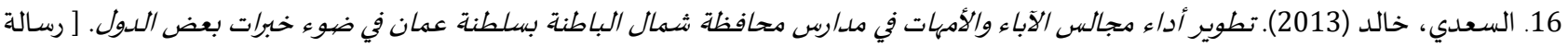
ماجستير، جامعة نزوى].

17. السلطان، فهد (2008).واقع التعاون بين المدرسة والمجتمع المحلي بمدينة الرياض. رسالة التربية وعلم النفس: (31): 83-122.

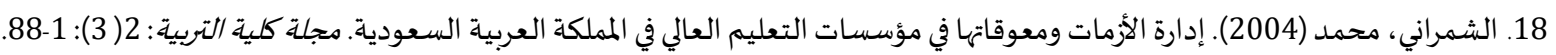

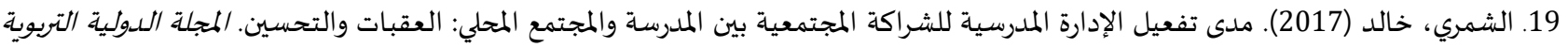
المتخحصصية: 6 (1): 258-248.

20. صبادق، حصة (2003). أساليب إدارة بعض أزمات النظام التعليمي القطري. مجلة التربية: (104): 233-263.

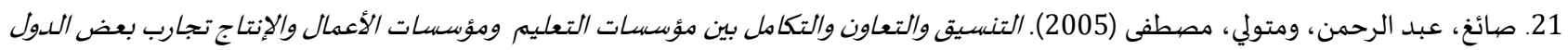

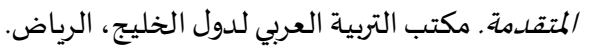

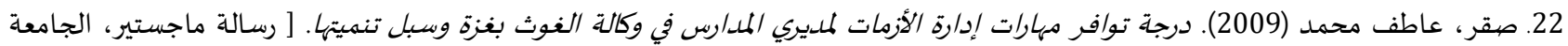
http:/search manumah.com/Record/ الإسلامية] . دار المنظومة.

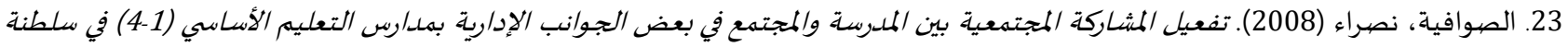
عمان. [رسالة ماجستير، جامعة السلطان قابوس].

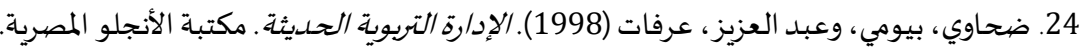
25. الطائي، رعد، وقداده، عيسى (2020). إدارة الجودة الشاملة. دار اليازوري العلمياة.

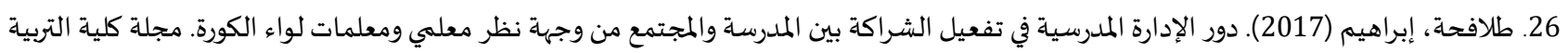
بأسيوط: 33(7): 203-177. 27. الطويل، هاني (2006). الإد/رة التعليمية مفاهيمر وآفاق. دار وائل للطباعة والنشر.

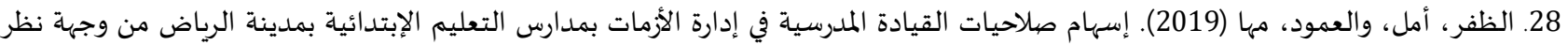

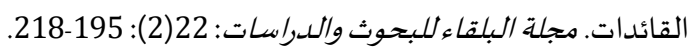


29. عاشور، محمد علي (2011). دور مدير المدرسة في تفعيل الشراكة بين المدرسة وبين المجتمع المحلي في سلطنة عمان. مجلة دراسات العلوم التربوية: 38: .1225-1205

30. عبد الوهاب، سميرة محمد، ومحمد، رشدي (2014) الأزمات المعات المدرسية وأسـاليب التعامل معها كما يدركها مديرو مدارس المرحلة الثانوية بدولة الكويت.

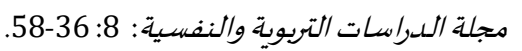

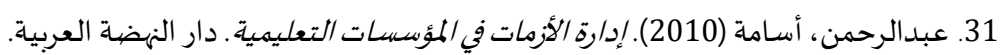

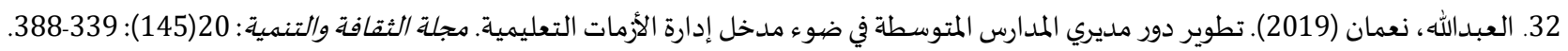

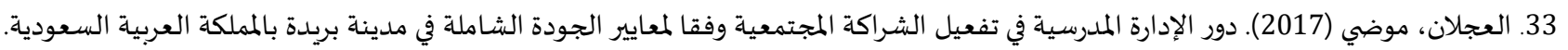

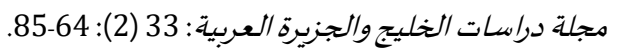

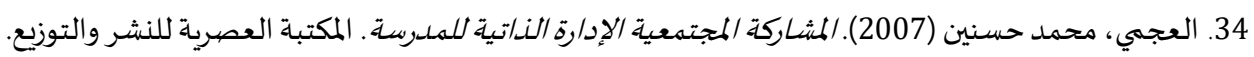

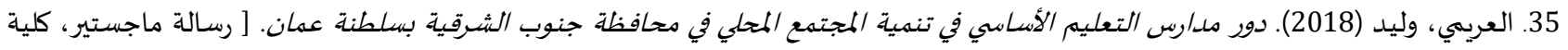
الإمارات للعلوم التربوية].

36. العوايشة، حيدر أحمد (2012). دور مديري المدارس الثانوانوية الحكومية في نشرثقافة الممدرسة المجتمعية في محافظة أربد. [ أطروحة دكتوراة، جامعة

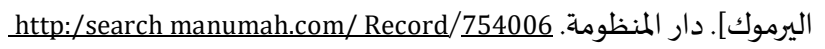

37. عيسان، صالحة، وكوفان، عبدالرحمن، الخنبشية، خولة (2018). فاعلية الشراكة المجتمعية بالمدارس الحكومية في سلطنة عمان من وجهة نظر

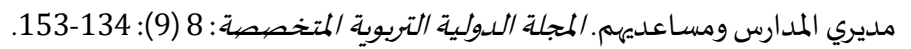

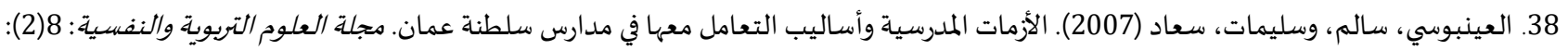
.84-63

39. فهي، محمد سيد (2013). الممدرسة المعاصرة والمجتمع. دار الوفاء للطباعة والنشر.

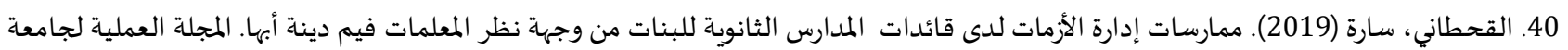
الملك فيصل: 20 (ملحق): 165-185. 41. القحطاني، عبد العزيز ( 2015). تطبيق الصلاحيات الممنوحة لمديري المدارس المبارئ التابعة للإدارة العامة للتربية والتعليم بمنطقة عسير. مجلة جامعة الملك سعود: 27 (3): 377. 42. أبو قحف، عبد السلام (2002). الإد/رة الاستراتيجية وإدارة الأزمات الممسرية . دار الوفاء لدنيا الطباعة والنشر.

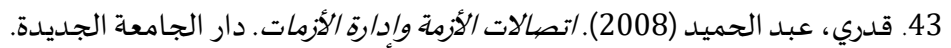

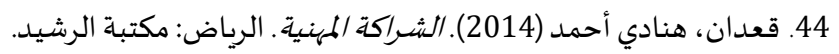

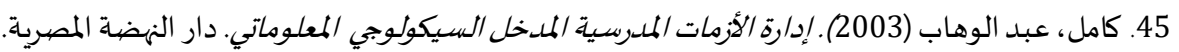

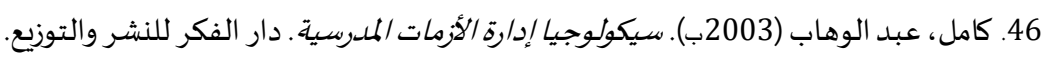

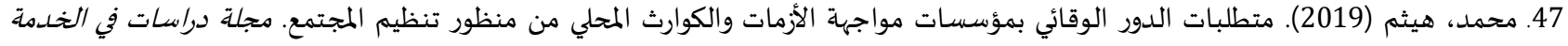

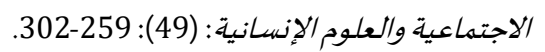

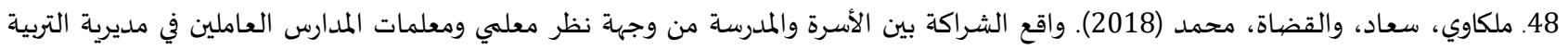

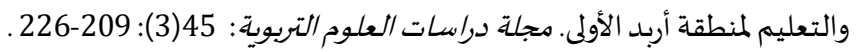

49. النوح، عبد العزيز ( 2015). دور إدارة المدرسة في تفعيل الشراكة بين المدرسة وبين المجتمع المحلي. محجلة دراسات الخليج والجزيرة العببية: 3 (2): 44 ـ

50. الهدمي، ماجد، ومحمد، جاسم ( 52 (2008). مبادئ إدارة الأزمات الاستراتيجية . زهران للنشر والتوزيع.

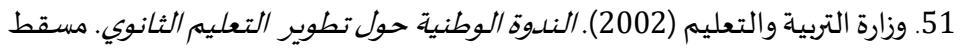

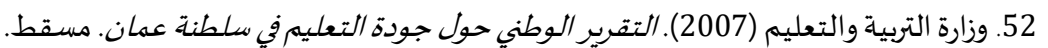

ثانياً: المراجع الأجنبية:

1. Atkinson, Marry. (2006). The New School Funding Arrangements 2006-2007: The School Perspective. Slough: National Foundation for Education Research.

2. Kyriakides, Leonidas. (2005). Evaluating School Policy Parents Working with their Children in Class. The Journal of Educational Research, 98(5): 281-298.

3. Little John, Robert, R (1998). Crisis Management: A Team Approach. New York: American Management Association.

4. Manasee, A. l. (2003). Principals as leaders of high performing systems. Educational Leadership, 41(5): 42-48. 
المجلة الدولية للدراسـات التربوية والنفسية

International Journal of Educational \& Psychological Studies (EPS)

Journal Homepage: https://www.refaad.com/views/EPSR/Home.aspx

www.refaad.com

ISSN: 2520-4149 (Online) 2520-4130 (Print)

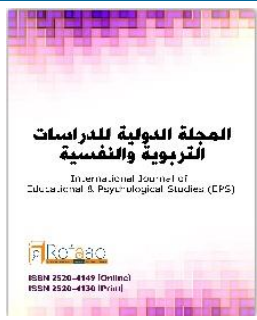

\section{The reality of activating the school administration for community partnership according to the requirements of educational crisis management in the Sultanate of Oman}

\section{Nasra bint Saleh AlAbri 1, Aieman Ahmad Al-Omari ${ }^{2}$, Amal bint Rashid AlKiymi ${ }^{3}$}

${ }^{1}$ postgraduate student, Department of Educational Assets and Administration, College of Education, Sultan

Qaboos University, Sultanate of Oman

2 Professor Doctor, Department of Educational Assets and Administration, College of Education, Sultan Qaboos University, Sultanate of Oman

${ }^{3}$ Assistant Professor, Department of Educational Assets and Administration, College of Education, Sultan Qaboos University, Sultanate of Oman

${ }^{1}$ nasra.alabri@moe.om, 2 a.alomari@squ.edu.om, ${ }^{3}$ kiyomi@squ.edu.om

Received : 6/6/2021 Revised : 15/6/2021 Accepted : 20/6/2021 DOI : https://doi.org/10.31559/EPS2021.10.2.9

Abstract: This study aimed to identify the reality of activating the school administration for community partnership according to the requirements of crisis management in the Sultanate of Oman from the teachers' point of view, and in order to achieve the study objectives and show the impact of the study variables (gender, governorate, years of experience), the descriptive approach was used, and a questionnaire was designed consisting of (72) items. They are divided into six dimensions: communication and information, preventive planning and forecasting, leadership skills and building human relationships, obstacles related to the local community, obstacles related to the school, obstacles related to school administration. The study sample was chosen, which represented $5 \%$ of the study population as it reached (1466) male and female teachers. The results of the study highlighted; The estimates of the study sample members on the reality of activating the school administration of community partnership in accordance with the requirements of educational crisis management in the Sultanate of Oman were high in the dimension of leadership skills and building human relations, medium in the dimension of communication and information, and low in the dimension of preventive planning and forecasting. As for the results related to the obstacles facing the school administration, the obstacles related to the school and the obstacles related to the school administration came to a high degree, while they were moderate in the obstacles related to the local community. And the presence of statistically significant differences according to the sample members' estimates of the reality of activating the school administration of community partnership according to the requirements of managing educational crises in the Sultanate of Oman due to the gender variable in the leadership skills and building human relations dimension for the benefit of females, and the governorate variable in the dimension of communications and information for the benefit of Muscat Governorate. And there were statistically significant differences for the governorate variable in the obstacles related to the local community in favor of Al Dhahirah Governorate, and the obstacles related to school administration in favor of North Al Sharqiya Governorate. In light of these results, a number of suggested procedures and recommendations have been developed, the most important of which are: Giving school administrations the powers to attract different community bodies without referring to the directorates, which facilitates the activation of community partnership in accordance with the requirements of managing educational crises.

Keywords: School administration; community partnership; educational crisis management; Oman.

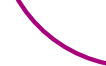

\section{References:}

1. 'ashwr, Mhmd 'ly (2011). Dwr Mdyr Almdrsh Fy Tf'yl Alshrakh Byn Almdrsh Wbyn Almjtm' Almhly Fy Sltnt 'man. Mjlt Drasat Al'lwm Altrbwyh: 38: 1205-1225.

2. 'bd Alwhab, Smyrh Mhmd, Wmhmd, Rshdy (2014). Alazmat Almdrsyh Wasalyb Alt'aml M'ha Kma Ydrkha Mdyrw Mdars Almrhlh Althanwyh Bdwlt Alkwyt. Mjlt Aldrasat Altrbwyh Walnfsyh: 8: 36-58.

3. Alamyr, Mhmd 'ly (2003). Khtt Altwar' Wedarh Alazmat. Almjlh Alflstynyh Lltrbyh Almftwhh 'n B'd: 1(1): 323-354. 
4. Ahmd, 'sam Bdry (2017). Tkaml Jhwd Almnzmat Alhkwmyh Walahlyh Fy Mwajht Alkwarth Walazmat Almjtm'yh. ]Atrwht Dktwrah, Jam't Asywt[.

5. Brkat, Zyad (2007). Msadr Alazmat Kma Ydrkha Tlbh Jam't Alqds Almftwhh. Almjlh Alflstyynyh Llt'lym Almftwh Walt'lym Alelktrwny: 1(1): 323-354.

6. Albymany, Wdad (2013). Dwr Mdyrat Almdars Fy Edarh Alazmat Walkwarth. Mjlt Drasat Alkhlyj Waljzyrh Al'rbyh: 11(2): 120-128.

7. Dhawy, Bywmy, W'bd Al'zyz, 'rfat (1998). Aledarh Altrbwyh Alhdythh. Mktbt Alanjlw Almsryh.

8. Alhbsy, Rhmh (2011). Waq' Almsharkh Almjtm'yh Fy Sn' Alqrar Altrbwy Fy Alnzam Alt'lymy Al'am Bsltnh 'man. ]Rsalt Majstyr, Jam't Alsltan Qabws[.

9. Alhbyb, 'bd Alrhmn, Walfayz, Fayz (2014). Edart Alazmat Fy Mdars Alt'lym Al'am Bedarh Altrbyh Walt'lym Fy Mdynt Alryad. Mjlt Altrbyh: (161): 540-581.

10. Alhlw, Ghsan (2009). Alazmat Almdrsyh Fy Almdars Althanwyh Alhkwmyh Fy Mdyryat Shmal Aldfh Alghrbyh. Mjlt Jam't Alnjah Llabhath (Al'lwm Alensanyh): 24: 223-262.

11. Hmdwnh, Hsam (2006). Mmarsh Mdyr Almdrsh Althanwyh Lmharh Edarh Alazmat Fy Mhafzt Ghzh. Mjlt Al'lwm Alnfsyh Waltrbwyh: 3(2): 112-118.

12. Alj'ydy, Walsmyh (2014). Dwr Aledarh Almdrsyh Fy Tf'yl Alshrakh Almjtm'eyh Byn Almdars Althanwyh Llbnat Walmjtm' Almhly. Rsalt Alkhlyj Al'rby: 132(35): 189.

13. Jawysh, F'ad Mhmd (2002). Tswr Mstqbly Ldwr Aledarh Almdrsyh Fy Tkhtyt Al'laqh Byn Almdrsh Wb'd Wsa't Altrbyh Fy Almjtm' Almsry.] Rsalt Dktwrah, Jam't Alqahrh[.

14. Aljhny, 'bdallh (2010). Asalyb Atkhad Alqrar Fy Edarh Alazmat Almdrsyh Mn Wjht Nzr Mdyry Almdars Bmhafzt Ynb'.] Rsalh Majstyr, Jam't Almlk 'bdal'zyz[.

15. Alkhmys, Abtsam, Walsalhy, Khald (2019). Waq' Ttbyq Qa'dat Almdars Althanwyh Latkhad Alqrar Fy Edart Alazmat Almdrsyh Bmntqh Alqsym. Almjlh Aldwlyh Llt'lym Balentrnt: Almjld Alawl: 35-64.

16. Alkhtyb, Rdah (2006). Almdrsh Almjtm'yh Wt'lym Almstqbl. 'alm Alktb Alhdyth Llnshr Waltwzy'.

17. Als'dy, Khald (2013). Ttwyr Ada' Mjals Alaba' Walamhat Fy Mdars Mhafzt Shmal Albatnh Bsltnh 'man Fy Dw' Khbrat B'd Aldwl. ] Rsalt Majstyr, Jam't Nzwa[.

18. Sa'gh, 'bd Alrhmn, Wmtwly, Mstfa (2005). Altnsyq Walt'awn Waltkaml Byn M'ssat Alt'lym Wm'ssat Ala'mal Walentaj Tjarb B'd Aldwl Almtqdmh. Mktb Altrbyh Al'rby Ldwl Alkhlyj, Alryad.

19. Sadq, Hsh (2003). Asalyb Edart B'd Azmat Alnzam Alt'lymy Alqtry. Mjlt Altrbyh: (104): 233-263.

20. Alsby'y, Nwrh, Wsnbl, Fa'qh (2019). Mttlbat Alshrakh Almjtm'yh Wm'wqatha Mn Wjht Nzr Almdyrat Walm'lmat Balmdars Althanwyh Bmhafzt Alkhrmh Wtwab'ha. Mjlt Al'lwm Alnfsyh Waltrbwyh: 3(25): 74-94.

21. Alshmrany, Mhmd (2004). Edart Alazmat Wm'wqatha Fy M'ssat Alt'lym Al'aly Fy Almmlkh Al'rbyh Als'wdyh. Mjlt Klyt Altrbyh: 2(3): 1-88.

22. Alshmry, Khald (2017). Mda Tf'yl Aledarh Almdrsyh Llshrakh Almjtm'yh Byn Almdrsh Walmjtm' Almhly: Al'qbat Walthsyn. Almjlh Aldwlyh Altrbwyh Almtkhssh: 6(1): 248-258.

23. Alsltan, Fhd (2008). Waq' Alt'awn Byn Almdrsh Walmjtm' Almhly Bmdynh Alryad. Rsalt Altrbyh W'lm Alnfs: (31): 83122.

24. Sqr, 'atf Mhmd (2009). Drjt Twafr Mharat Edart Alazmat Lmdyry Almdars Fy Wkalh Alghwth Bghzh Wsbl Tnmytha. ] Rsalt Majstyr, Aljam'h Aleslamyh [. Dar Almnzwmh. 545174 Http:/Search Manumah.Com/Record/

25. Alswafyh, Nsra' (2008). Tf'yl Almsharkh Almjtm'yh Byn Almdrsh Walmjtm' Fy B'd Aljwanb Aledaryh Bmdars Alt'lym Alasasy (1-4) Fy Sltnt 'man. ]Rsalt Majstyr, Jam't Alsltan Qabws[.

26. Alta'y, R'd, Wqdadh, 'ysa (2020). Edart Aljwdh Alshamlh. Dar Alyazwry Al'Imyh.

27. Tlafhh, Ebrahym (2017). Dwr Aledarh Almdrsyh Fy Tf'yl Alshrakh Byn Almdrsh Walmjtm' Mn Wjht Nzr M'lmy Wm'lmat Lwa' Alkwrh. Mjlt Klyt Altrbyh Basywt: 33(7): 177-203.

28. Altwyl, Hany (2006). Aledarh Alt'lymyh Mfahym Wafaq. Dar Wa'l Lltba'h Walnshr.

29. Alzamly, 'ly, Walghnbwsy, Salm, Wslyman, S'ad (2007). Alazmat Almdrsyh Wasalyb Alt'aml M'ha Fy Mdars Sltnt 'man. Mjlt Al'lwm Altrbwyh Walnfsyh: 8(3): 63-84.

30. Alzfr, Aml, Wal'mwd, Mha (2019). Esham Slahyat Alqyadh Almdrsyh Fy Edart Alazmat Bmdars Alt'lym Alebtda'yh Bmdynt Alryad Mn Wjht Nzr Alqa'dat. Mjlt Alblqa' Llbhwth Waldrasat: 22(2): 195-218. 